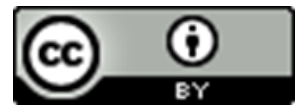

\title{
O CULTO EGÚNGÚN NO BRASIL DIÁSPORA, ANCESTRALIDADE E RESISTÊNCIA NEGRA NAS CIDADES BRASILEIRAS
}

Resumo: O presente trabalho tem como objetivo revelar e discutir as relações étnicoraciais, sobretudo, o racismo presente nas cidades brasileiras a partir do processo de diáspora do culto Egúngún no Brasil e suas táticas de resistência negra através da ancestralidade no espaço urbano brasileiro. Problematizando a relação terreiro de candomblé e cidade, opressão da sociedade mais ampla x resistência negra em três períodos: a perseguição policial e criminalização ao culto nos anos 1920-40; a especulação imobiliária e a expulsão ' 'branca" nos anos 1960-80; e a perseguição dos cultos neopentecostais e a intolerância religiosa na atualidade. Essa relação se dará através do desvelamento histórico do terreiro matriz, no século XX, do Culto aos Egum (o culto aos mortos ilustres, os ancestrais), o Omo Ilê Agboulá, localizado no povoado de Ponta de Areia, município de Itaparica. Esse terreiro foi tombado como Patrimônio Cultural do Brasil pelo IPHAN em 2015.

Palavras-chave: Diáspora, Ancestralidade, Candomblé, Egúngún, Cidade.

\section{THE EGÚNGÚN CULT IN BRAZIL: DIASPORA, ANCESTRALITY AND BLACK RESISTANCE IN BRAZILIAN CITIES}

Abstract: The present work aims to reveal and discuss ethnic-racial relations, above all, the racism present in Brazilian cities from the Diaspora process of the Egúngún cult in Brazil and its black resistance tactics through ancestry in the Brazilian urban space. Questioning the relationship between Candomble and the city, oppression of the wider society $\mathrm{x}$ black resistance in three periods: police persecution and criminalization of worship in the 1920s-1940s; real estate speculation and 'white' expulsion in the 1960s1980s; and the persecution of neo-Pentecostal cults and religious intolerance today. This relationship will take place through the historical unveiling of the mother terreiro, in the 20th century, of the Cult of Egum (the cult of the illustrious dead, the ancestors), the Omo Ilê Agboulá, located in the village of Ponta de Areia, municipality of Itaparica. This terreiro was listed as Cultural Heritage of Brazil by IPHAN in 2015.

\footnotetext{
${ }^{1}$ Arquiteto e Urbanista, Mestre em Arquitetura e Urbanismo pelo PPGAU-UFBA, na linha de Teoria e Crítica da Arquitetura e Urbanismo, área de concentração em Urbanismo, e Doutor em Arquitetura e Urbanismo pelo PPGAU-UFBA, na linha de Restauração, Conservação e Gestão de Bens Patrimoniais, área de concentração em Urbanismo. Atualmente é Professor Adjunto da FAUFBA. ORCID: https://orcid.org/0000-0003-4414-2521 ; E-mail: velame.fabio@gmail.com
} 
Keywords: Diaspora, Ancestrality, Candomblé, Egúngún, City.

\section{EL CULTO EGÚNGÚN EN BRASIL: DIÁSPORA, ANCESTRALIDAD Y RESISTENCIA NEGRA EN CIUDADES BRASILEÑAS}

Resumen: El presente trabajo tiene como objetivo revelar y discutir las relaciones étnico-raciales, sobre todo, el racismo presente en las ciudades brasileñas del proceso de la diáspora del culto Egúngún en Brasil y sus tácticas de resistencia negra a través de la ascendencia en el espacio urbano brasileño. Cuestionando la relación entre Candomblé y la ciudad, la opresión de la sociedad en general x la resistencia negra en tres períodos: persecución policial y criminalización del culto en las décadas de 1920 y 1940; especulación inmobiliaria y expulsión 'blanca' en las décadas de 1960 y 1980; y la persecución de los cultos neo-pentecostales y la intolerancia religiosa en la actualidad. Esta relación se llevará a cabo a través de la presentación histórica de la madre terreiro, en el siglo XX, del Culto de Egum (el culto de los ilustres muertos, los antepasados), el Omo Ilê Agboulá, ubicado en la aldea de Ponta de Areia, municipio de Itaparica. Este terreiro fue catalogado como Patrimonio Cultural de Brasil por IPHAN en 2015.

Palabras clave: Diáspora, Ancestralidad, Candomblé, Egúngún, Ciudad.

\section{LE CULTE EGÚNGÚN AU BRÉSIL: DIASPORA, ANCESTRALITÉ ET RÉSISTANCE NOIRE DANS LES VILLES BRÉSILIENNES}

Résumé: Le présent travail vise à révéler et à discuter des relations ethno-raciales, avant tout, le racisme présent dans les villes brésiliennes à partir du processus de diaspora du culte Egúngún au Brésil et ses tactiques de résistance noire à travers l'ascendance dans l'espace urbain brésilien. Interroger la relation entre Candomblé et la ville, oppression de la société au sens large x résistance noire en trois périodes: persécution policière et criminalisation du culte dans les années 1920-40; spéculation immobilière et expulsion «blanche» dans les années 1960-1980; et la persécution des cultes néo-pentecôtistes et de l'intolérance religieuse aujourd'hui. Cette relation se fera à travers le dévoilement historique de la mère terreiro, au XXe siècle, du Culte d'Egum (le culte des illustres morts, les ancêtres), l'Omo Ilê Agboulá, situé dans le village de Ponta de Areia, commune d'Itaparica. Ce terreiro a été inscrit au patrimoine culturel du Brésil par l'IPHAN en 2015.

Mots-clés: Diaspora, Ancestralité, Candomblé, Egúngún, Ville.

\section{1 - O CULTO EGÚNGÚN NA ÁFRICA E NO BRASIL}

O presente trabalho trata da resistência do Omo Ilê Aboulá, um templo da sociedade de culto aos Egum $^{2}$, situado no povoado de Ponta de Areia, na ilha de

\footnotetext{
${ }^{2}$ Existiam na África, entre as sociedades Iorubás, diversas sociedades secretas masculinas e femininas. As masculinas eram: a Sociedade Secreta de culto aos Egungum, ou Egum, representava linhagens, clãs, famílias, dinastias reais, protegia cidades e regiões, sagrava os reis, em suma, eram os ancestrais ilustres
}

Revista da ABPN • v. 12, n. $34 \cdot$ Set - Nov 2020, p.99-130 
Itaparica, aos processos de violência impostos pela racialização do espaço urbano nas cidades brasileiras. Na África, os Egum (ver Fig.01) eram os ancestrais masculinos que representavam descendências nobres, reis, dinastias reais e famílias nobres, pais fundadores das cidades e linhagens, guerreiros, sacerdotes e outras lideranças que tinham conseguido, durante a vida, certo prestígio e poder. O culto dos Egum na África, segundo Renato da Silveira, tinha um caráter plurifuncional, possuía funções constitucionais, políticas, judiciárias, de controle da moralidade pública e do comportamento social, controle religioso, assim como funções econômicas, sociais, militares e artísticas:

Constitucionalmente, os chefes das linhagens, que também eram sacerdotes do culto dos ancestrais familiares, eram membros obrigatórios da sociedade Egúngún. Os festivais anuais do culto dos mortos eram momentos privilegiados, nos quais as linhagens demonstravam, publicamente a lealdade ao rei. Por dentro dessa rede de relações, em Oyó a Sociedade Egúngún representava particularmente o poder social masculino [...] O Alápinnì estava acima do Alágbà, sumo sacerdote dos diversos terreiros Egúngún, era uma chefia de carácter mais político, mas ligada ao aparelho de Estado, enquanto que o Alágbà, que tinha relações diretas com os chefes das linhagens e dos bairros urbanos, era o líder ritual, com vínculo mais direto com a sociedade [...] Além da cerimônia anual de todos os adeptos do culto em uma dada região, o OdunÉgún, os eguns participavam de certas cerimônias costumeiras das linhagens praticantes do culto dos mortos, como batizados, funerais, ou cerimônias abertas a toda a comunidade, reconciliações, lavagens e inaugurações [...] Por outro lado, frequentemente os eguns dos obás marchavam à frente dos exércitos dirigindo-se aos combates, como por exemplo Alakoro, egúngún Sàngó em Oyó. Babayemi cita os casos do Imperador Atiba de Oyó, que comandou seu Exército na batalha de Epo vestido com roupas egúngún, e do Obá de Ibadan, Olúyole, que costumava liderar suas tropas com a máscara e a vestimenta do seu egum. [...] Certas categorias sociais que desempenhavam funções econômicas e terapêuticas importantes também tinham seus eguns próprios, como Olóògun, patrono dos curandeiros herbonistas, ou Láyèwú, também Egúngún Ode, patrono dos caçadores [...] Os entertainers, artistas de teatro e circo, nas cidades de Oyó e do norte também tinham seus antepassados ilustres divinizados, que desempenhavam um papel tremendamente visível, incrementando o lazer público. Tais eguns, chamados de 'trikster egungun'” na literatura anglo-saxônica, eram cantadores, dançarinos, saltibancos,

que tomavam forma corporal e voltavam do mundo dos mortos para ter com seus descendentes, com os seus filhos, assim como equilibrar o poder e a influência feminina na sociedade Iorubá. As femininas eram: Sociedade Ialodé, voltada para a discussão pública dos assuntos civis entre as mulheres, resoluções de questões comerciais e jurídicas. Ialodé também era o título mais honorifico que uma mulher poderia receber e que a colocava instantaneamente à frente das demais mulheres, era a cabeça, a líder das mulheres, representava as mulheres de sua sociedade no palácio real, no conselho e nos tribunais; Sociedade Obóni, uma complexa sociedade, instituição religiosa e política que abrangia mulheres representantes de vários níveis da sociedade Iorubá, e que contrabalançava o poder dos reis; Sociedade Geledé, voltada para o culto das mães anciãs, das velhas feiticeiras; Sociedade Eleéko era uma sociedade antiga Iorubá, voltada ao culto da divindade feminina Oba. (SANTOS, 1998, p. 115). 


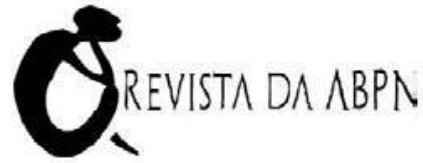

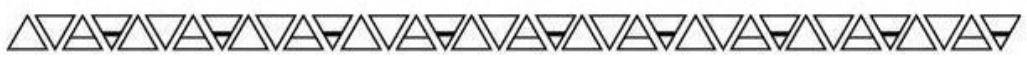

especialistas na percussão dos tambores bàtá e dùndún, apresentavam-se regularmente em frente ao palácio, nos mercados e outros lugares abertos para divertir a população. Entre eles estão Alare, Agbegijo e Alarinjo, o qual só se apresentava dançando (SILVEIRA, 2006, p. 427).

Roger Bastide destaca o caráter econômico, social e religioso do culto aos Egum, que tinham também as funções de receber as primeiras colheitas, realizar a bênção dos campos para a semeadura, cuidar dos moribundos e ir à residência das pessoas que estavam morrendo:

As grandes festas agrícolas nos países iorubás, a da plantação, a da "desconsagração" das primeiras colheitas, são feitas sempre com evocação dos eguns. Essa primeira função da bênção dos campos pelos antepassados e das oferendas das primícias aos mortos parece ter desaparecido na Bahia. Efetivamente, nessa cidade, a grande festa dos eguns (ojé-messé, ilé nhanga ou nibi egum anangua) - que é uma cerimônia privada - tem lugar no dia 2 de novembro, dia dos mortos, por sincretismo com o catolicismo. Do mesmo modo que os diablitos de Cuba, a sociedade dos eguns ia outrora às casas onde havia mortos ou moribundos. Mas essa função também desapareceu em nossos dias. As cerimônias não podem se realizar nas moradias particulares, e sim somente no interior dos candomblés ou na ilha de Itaparica. (BASTIDE, 2001, p. 136).

Figura 01: Um Egúngún pelas ruas da cidade de Quidah, no Benim.

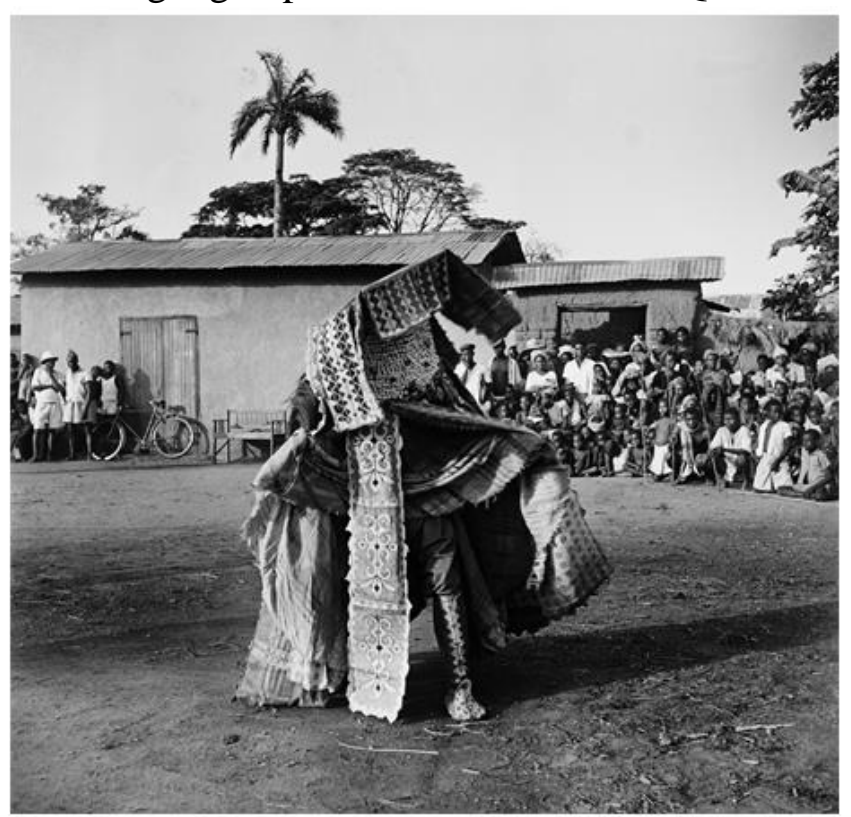

Fonte: VERGER, Pierre. Benim, 1948-1953.

Na Bahia, o culto aos Egum (ver Fig.02) perdeu estas atribuições em virtude da escravidão, que desestruturou suas relações sociais, econômicas e políticas. Aqui o culto aos Egum passou por transformações, modificações e acréscimos, circunscrevendo-se atualmente à evocação dos ancestrais ilustres afro-brasileiros da sociedade e de alguns 
Egum africanos que foram preservados, para fornecer conselhos, orientações, caminhos para os vivos, os seus descendentes em seu fluxo de vida, em seus problemas cotidianos, eventuais, específicos de cada um ou de toda a sociedade.

Figura 02: Babá Alapalá no Omo Ilê Agboulá, no Barro Vermelho

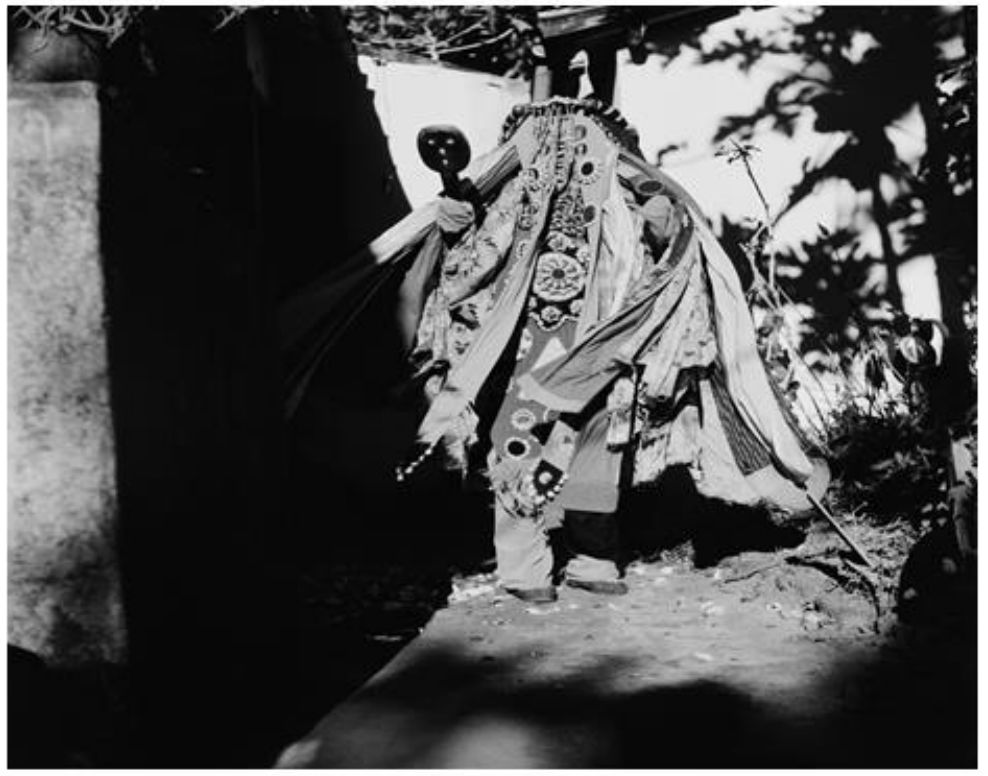

Fonte: VERGER, Pierre, 1958

O Omo Ilê Agboulá é o herdeiro dos terreiros de candomblé de Egum do século XIX e a matriz de todos os terreiros de Egum do século XX, no Brasil. Ele recebeu não apenas os rituais, as músicas, os fundamentos, ou seja, a tradição do culto aos Egum, mas também toda uma linhagem de ancestrais sejam eles africanos ou afro-brasileiros que pertenciam aos terreiros de Egum do século XIX. Atualmente, é referência para todos os demais membros dos terreiros de Egum no país, pois, embora sejam estes independentes, para lá os Ojés (sacerdotes do culto) sempre voltam quando têm algum problema com algum Egum ou Exu de Egum, procurando os sacerdotes mais velhos e experientes do Omo Ilê Aboulá para resolver os seus problemas.

Por ser, para os membros da família extensa do culto aos Egum do povoado de Ponta de Areia, o seu ponto de referência, é o seu centro irradiador de proteção, segurança, um porto seguro, pois é o lugar por excelência da imanência do sagrado, já que é a morada de seus pais, avós, bisavós de ancestrais longínquos que vieram da África; além de ser o lugar de contato e abertura para o além, o Orum. O Omo Ilê Aboulá é o elemento central e fundamental para eles, quer seja no seu povoado, quer 
seja no mundo onde habitam e que rege o seu cotidiano. O dia-a-dia deles vincula-se intrinsecamente ao culto aos Egum, que possui no Omo Ilê Aboulá a sua morada.

O culto dos Egum na Bahia remonta ao início do século XIX. Nesse período, já existiam em Salvador diversos terreiros voltados especificamente à invocação e à adoração dos ancestrais. Segundo a tradição oral e confirmada pelo projeto Égúngún ${ }^{1}$, assim se sucederam os terreiros de culto aos Egum no Brasil, nos séculos XIX e XX: terreiro de Vera Cruz, terreiro do Mocambo, terreiro da Encarnação, terreiro do Tuntum, terreiro do Corta Braço, terreiro da Quitandinha do Capim, terreiro do Matatu e terreiro da Preguiça, todos eles fundados no século XIX, entretanto nenhum deles existe mais. O terreiro Omo Ilê Aboulá, terreiro Ilê Olokotum, terreiro Ilê Obaladê, terreiro Ilê Omo Nilê, terreiro Ilê Marobó, terreiro Ilê Babá Adelorum, terreiro Ilê Babá Kiobê, terreiro Ilê Atilewa, terreiro Ilê Axipá, terreiro Ilê Babá Adebolá, terreiro Ilê Babá Lojadé, e terreiro Ilê Babá Onilá, todos esses foram fundados ao longo do século XX.

O terreiro de Vera Cruz estava localizado na Aldeia de Vera Cruz, a mais antiga de todas as freguesias da Ilha de Itaparica, na Bahia de Todos os Santos. Esse terreiro foi fundado por volta de 1820 pelo africano Tio Serafim, sendo dirigido por ele até a sua morte. Tio Serafim, que faleceu com cerca de cem anos, entre 1905 e 1910, invocava, fazia aparecer e falava com o Egum de seu próprio pai, o qual ainda é cultuado hoje em dia sob o mesmo nome de Babá Okulelê. O terreiro do Mocambo, fundado em 1830, estava localizado também em Itaparica, na fazenda chamada Mocambo, onde existia um grande número de escravos. Seu chefe foi o africano nagô Marcos Pimentel (conhecido como Marcos-o-Velho), que comprando sua própria alforria, conseguiu regressar à África, onde permaneceu por vários anos, melhorando e aperfeiçoando seus conhecimentos litúrgicos nesse movimento diaspórico. Viajou para a África levando o seu filho Marcos Teodoro Pimentel, que lá foi iniciado nos segredos do culto aos Egum. Voltando mais tarde para a Bahia, em meados do século XIX, os dois trouxeram o assento de Babá Olukotum (SANTOS, 1981, p.159), fluxos da diáspora negra entre Bahia e Nigéria.

\footnotetext{
1 Projeto desenvolvido pela SECNEB (Sociedade de Estudos da Cultura Negra no Brasil sob a coordenação da antropóloga Juana Santos) em 1980, com o objetivo de: coletar e preservar o patrimônio áudio visual do Omo Ilê Aboulá, as suas principais músicas e festas; registrar a história de todos os terreiros de culto aos Egum no século XIX, as genealogias entre as casas, as fundações e fechamentos dos terreiros de Egum, seus principais líderes e dirigentes até a fundação do Omo Ilê Aboulá nos anos de 1940; e por fim alguns aspectos singulares do culto aos Egum.

${ }^{2}$ Babá em Iorubá quer dizer Pai, constitui também uma forma de denominar o Egum.
} 
Esse Egum é considerado por todos os membros da sociedade de culto um dos ancestrais de todo o povo nagô, considerado o Olori Egum, a cabeça, o ancestral primordial. Os dois então fundaram o Terreiro do Tuntum, chamado também na época de terreiro Ilê Olokotum. O Egum de Marcos-o-Velho é cultuado hoje sob o nome de Babá Soadê.

O terceiro terreiro de Egum foi o terreiro de Encarnação. Fundado por volta de 1840, estava também localizado na Ilha de Itaparica. Seu fundador e primeiro Alabá foi um filho de Tio Serafim, chamado de João-Dois-Metros por causa de sua enorme altura. Esse terreiro tem enorme importância, visto que foi lá que teria sido invocado e aparecido pela primeira vez Babá Agboulá, um dos patriarcas dos Iorubás.

O terreiro do Tuntum, fundado em 1850, também estava situado na Ilha de Itaparica, no antigo reduto de africanos denominado Tuntum, onde é hoje o bairro do Barro Branco em Ponta de Areia. Esse terreiro teve como líder o filho de Marcos-oVelho, Marcos Teodoro Pimentel (o Tio Marcos), que morreu já quase centenário por volta de 1935 .

Tio Marcos possuiu o título de Alapini Ipekun Ojé, sacerdote supremo do culto aos Egum, no Brasil. Na tradição nagô, o Alapini representava todos os membros das sociedades de Egum no Afin, no palácio real de Oyo. Tio Marcos faleceu por volta de 1935. Com sua morte, o terreiro do Tuntum fechou as suas portas.

O culto a Babá Olokotum continuou, todavia, através de seu sobrinho Arsênio Ferreira dos Santos, que possuía o título de Alabá, o chefe do terreiro e de uma sociedade de culto aos Egum. Este foi morar no estado do Rio de Janeiro, no município de São Gonçalo, levando consigo o assento de Babá Olokotum.

Depois do falecimento de Arsênio, o assento de Babá Olokotum retornou para a Bahia, através de Deoscóredes M. dos Santos, conhecido como Mestre Didi Axipá, que foi o presidente e Alabá do Ilê Axipá. Sua mãe, a famoso Ialorixá do Ilê Axé Opô Afonjá Maria Bibiana do Espírito Santo, a Mãe Senhora, que ocupava o mais alto cargo da hierarquia feminina do culto aos Egum, Iá Egbé, o levou para receber as bênçãos dos Egum, pois ele sofria de uma doença grave, sem solução médica, que a Mãe Senhora acreditava ser oriunda de um feitiço de suas inimigas.

Considerava que os feitiços feitos para ela recaíam sobre o seu filho, que não possuía proteção alguma, pois, sendo ela uma Ialorixá, possuía a proteção dos Orixás, ao passo que seu filho não havia sido iniciado no candomblé. 
Ela recorreu a todas as divindades, entretanto não resolveu os problemas de saúde do filho, somente os Egum do terreiro do Tuntum curaram o seu filho. Então ela a entregou a Marcos Teodoro Pimentel para que ele pudesse iniciá-lo mais tarde nos segredo do culto dos Egum. Essa criança era Mestra Didi, que se tornaria, mais tarde, o Alapini do culto aos Egum no Brasil.

O terreiro do Corta Braço, fundado no final do século XIX, estava situado na Estrada das Boiadas, no atual bairro da Liberdade, em Salvador, fora, portanto, da Ilha de Itaparica. Esse terreiro tinha como um dos Ojé o conhecido João-Boa-Fama e era liderado pelo lendário Tio Opé. João Boa Fama iniciou alguns jovens na Ilha de Itaparica que se juntariam com os descendentes de Tio Serafim e Tio Marcos para fundarem mais tarde, na primeira metade do século XX, o Ilê Omo Aboulá. O sexto terreiro de Egum foi o terreiro da Quitandinha do Capim. Fundado no final do século XIX, estava localizado na Quitandinha do Capim, em Salvador, e cultuava os Egum Olu-Apelê e Olojá Orum. O de Matatu, fundado também no final do século XIX por Tio Agostinho, situava-se no Matatu de Brotas, em Salvador. Esse terreiro se tornou ponto de concentração de vários Ojés de outras casas, inclusive o Alapini Tio Marcos do Tuntum.

O último terreiro de Egum fundado no século XIX foi o terreiro da Preguiça, que estava localizado ao lado da igreja da Conceição da Praia, no início da ladeira da Preguiça. Durante o século XIX e no início do século XX, os fiéis, os sacerdotes, os chefes de culto, ou seja, os membros de cada um deles, freqüentavam-se, visitavam-se, relacionavam-se, trocando experiências, conhecimentos, unindo esforços de resistência, primeiramente ao cativeiro, à escravidão e, em seguida, às perseguições policiais.

Organizaram-se constituindo uma irmandade, uma poderosa sociedade secreta com características bem definidas. A partir desse inter-relacionamento, foi que os antigos terreiros sucederam uns aos outros, fecharam-se as suas portas e todos eles vieram, na primeira metade do século XX, a se condensar no Omo Ilê Aboulá. O Omo Ilê Aboulá é, hoje, no Brasil, a síntese direta e indireta dos terreiros de Egum do século XIX na Bahia, sendo a matriz de todos os terreiros dedicados exclusivamente ao culto dos Egum na atualidade.

A partir de 1955, ocorreu o processo inverso do que ocorreu no final do século XIX e início do século XX, ou seja, ocorreu a reterritorialização do culto dos Egum em várias localidades de Ponta de Areia e povoados vizinhos. Começou a proliferação de 
terreiros de culto aos Egum, todos oriundos do Omo Ilê Agboulá, extrapolando inclusive os limites da Bahia, sendo que este processo se intensificou nestes últimos vinte cinco anos.

Hoje existem no Brasil doze terreiros de Egum. Em Ponta de Areia, na Ilha de Itaparica, existem seis: o Omo Ilê Agboulá, no bairro do Bela Vista, cujo Alabá é o Ojé Abá Balbino Daniel de Paula; o Ilê Olokotum, que é o antigo Ilê Oiá, no bairro do Barro Branco, sendo o seu Alabá o Ojé Abá Guegueu; o Ilê Obaladê, também localizado no Barro Branco, tendo como seu Alabá o Ojé Abá Eduardo; o Ilê Omo Nilê, localizado ainda no Barro Branco, sendo o seu Alabá o Ojé Abá Petú. No bairro da Misericórdia, existe o Ilê Marobó, tendo como Alabá o Ojé Abá Carneirinho; no bairro da Jurema, há o Ilê Babá Adelorum, cujo Alabá é o Ojé Tatu.

Oliveira (2012) considera as referências sociais, simbólicas, culturais e políticas da população negra como territórios e territorialidade, fundado por bases materiais e subjetivas. Logo, a territorialidade do axé, da ancestralidade e dos valores ancestrais negro africano estão presente no chão do território.

No povoado vizinho de Amoreira, também na ilha de Itaparica, existe apenas um terreiro de Egum, o Ilê Babá Kiobê, cujo Alabá é o Ojé Abá Budijó.

Na região metropolitana de Salvador, há três terreiros de culto aos Egum. O Ilê Atilewa, localizado próximo ao aeroporto, na cidade de Lauro de Freitas, cujo Alabá é o Ojé Abá Regi. O Ilê Axipá, que fica no bairro de Piatã em Salavdor, fundado por Mestre Didi. O Ilê Babá Adebolá, que ficava em Areia Branca e atualmente localiza-se em Simões Filho, cujo Alabá é Ojé Abá Manoel.

No Rio de Janeiro, na baixada fluminense, existem dois terreiros de Egum. O Ilê Babá Lojadé, cujo Alabá é o Ojé Abá Carlos; Ilê Babá Onilá, sendo o seu Alabá o Ojé Abá Laércio dos Santos.

Todos eles foram oriundos de dissidências internas do Omo Ilê Agboulá em virtude de disputas de hierarquias de culto aos Egum, notadamente nas disputas sucessórias do posto de Alabá quando um membro que disputava o cargo se sentia prejudicado e decidia abrir a sua própria casa. Outro fator determinante vem a ser um Ojé ou um grupo de Ojés achar que um determinado Egum de sua linhagem, um de seus ancestrais, merecia um pouco mais de atenção e destaque do que outros. É significativo também o fato de a abertura de novas casas ser uma forma de renda extra para 
determinados Ojés, pois o dinheiro oriundo dos serviços espirituais é repartido por menos sacerdotes, notadamente, com os outros Ojés Abás, os mais velhos.

Por ser herdeiro direto ou indireto dos terreiros de culto aos Egum do século XIX e a matriz dos terreiros do século XX, o Omo Ilê Agboulá constitui a referência afrobrasileira no culto aos ancestrais ilustres, os Egum no Brasil, e Egúngúm em África. O Omo Ilê Agboulá é prestigiado e respeitado por todos os outros templos de Egum no Brasil, pois os seus Ojés sempre regressam ao Omo Ilê Agboulá, nos períodos de festa, porque ele continua a ser a casa de todos os Ojés, independente dos seus terreiros de origem. Esse fato se deve ao aspecto de que o culto aos Egum ser uma sociedade que ultrapassa os limites dos terreiros, pois eles são "sócios" de um segredo, o segredo de como invocar os Egum e lidar com a morte, Ikú.

\section{2 - CIDADE RACIALIZADA: A PERSEGUIÇÃO POLICIAL E}

\section{CRIMINALIZAÇÃO AO CULTO NOS ANOS 1920-40; A ESPECULAÇÃO}

IMOBILIÁRIA E A EXPULSÃO “BRANCA' NOS ANOS 1960-80; E A

\section{PERSEGUIÇÃO DOS CULTOS NEO PENTECOSTAIS E A INTOLERÂNCIA RELIGIOSA NA ATUALIDADE}

O Omo Ilê Agboulá foi fundado no primeiro quarto do século XX, na localidade de Ponta de Areia próxima a praia, num local que, na atualidade, fica atrás da Capela de Nossa Senhora das Candeias em Ponta de Areia, no município de Itaparica. Foi fundado por Eduardo Daniel de Paula ${ }^{1}$, filho de nagôs, juntamente com seus familiares e com descendentes de Tio Marcos e Tio Serafim, antigos sacerdotes.

Entretanto, os anos ao longo das décadas de vinte e trinta e o início dos anos quarenta constituíram o auge da repressão e perseguição aos candomblés na Bahia ${ }^{2}$, o Omo Ilê Agboulá, nesse cenário, também sofreu uma perseguição voraz da polícia. $\mathrm{O}$ terreiro foi invadido, alvejado por tiros e destruído internamente pelos policiais como conta a edição do Jornal "A Tarde"' de 21 de junho de 1940:

\footnotetext{
${ }^{1}$ Eduardo Daniel de Paula é atualmente cultuado como o Egum chamado Babá Erim (Babá significa pai em Iorubá) e sua festa é no dia 24 de junho. Eduardo Daniel de Paula foi iniciado no culto aos Egum pelo Ojé Aba Tio Opé.

2 BRAGA, Julio. Na Gamela do Feitiço: Repressão e Resistência nos Candomblés da Bahia. Salvador: EDUFBA, 1995.
} 
A policia baiana, em feliz diligência, apreendeu anteontem, à noite, na Ilha de Itaparica, em Amoreiras, um casal de pai-de-santo e copioso material da liturgia fetichista. Há dias, queixaram-se ao Dr. Altino Teixeira, delegado auxiliar, os moradores de Amoreiras, contra aquele "terreiro", que os punha em constante desassossego. Os "'babalaôs" eram Antonio Daniel de Paula e um indivíduo conhecido como "Paizinho". O Dr. Altino Teixeira entendeu-se com o Sr. Secretário de Segurança e foi enviada para o local uma caravana de investigadores. Às $19 \mathrm{hs}$ de anteontem, a caravana cercou a casa, e em seguida, varejou-a. Eduardo Daniel de Paula, pai de Antonio, o chefe-mor mais conhecido como "Alibá" [sic] e sua esposa Margarida da Conceição, que estavam no interior da casa, foram detidos imediatamente. Continuando as buscas, os policiais encontraram grande quantidade de material próprio do culto fetichista; cadeira de resplendor e acolchoadas, caveiras e ossos; crânios de animais; um cetro de aço enfeitado de fitas de várias cores, tendo na parte superior uma pomba de metal e na inferior um espeto (catapó); uma imagem esculpida na pedra representando um deus barrigudo, muito semelhante a Buda (Deus Nanã); várias máscaras de madeira habilmente esculpidas; um quadro da "Mãe d'Água"; vários batuques, cabaças, etc. Todo este material foi transportado para esta capital, juntamente com os dois detidos, aqui chegando ontem à tarde. Os pais-de-santo principais, Antonio Daniel de Paula e "paizinho" Arsênio Ferreira dos Santos, que conseguiram escapar, estão sofrendo severa perseguição por parte de investigadores, que se acham no seu encalço. Eduardo (alibá) o pai de santo que se acha preso, explicou ao repórter, detalhadamente, a função de cada um daqueles objetos, segundo ele, com exceção das cadeiras, datam de muito antes da libertação dos escravos, tendo vindo talvez da África (BRAGA, 1995, p. 31).

Eduardo Daniel de Paula e sua esposa ficaram quase uma semana presos em Salvador, sendo libertados pelo delegado por medo de sofrer atentados a sua vida. Os outros dois líderes do culto aos Egum, na época, Antonio Daniel de Paula e "paizinho", Arsênio Ferreira dos Santos, não foram capturados por outras investidas policiais ao povoado, conseguiram fugir e se esconder da perseguição policial. Neste período, segundo Balbino Daniel de Paula, atual Alabá ${ }^{3}$ do Omo Ilê Agboulá, também começou um lento processo de ocupação e de adensamento urbano do povoado de Ponta de Areia, onde novas pessoas passaram a construir suas casas próximas ao local onde estava o terreiro. Assim, os membros da sociedade de culto aos Egum perderam a privacidade de realizar seu culto. No final de 1941, Eduardo Daniel de Paula conseguiu com a ajuda dos membros e amigos da sociedade comprar um terreno num lugar chamado de Barro Vermelho, em Ponto de Areia. Para lá, conseguiu finalmente realizar a mudança do Omo Ilê Agboulá, construindo um outro templo, com outras edificações,

\footnotetext{
${ }^{3}$ Denominação empregada para denominar um chefe de terreiro de Egum.
} 
com outros espaços, mas sendo o "mesmo"' templo, o Omo Ilê Agboulá, pois mantém os assentamentos de seus ancestrais.

Os membros do Omo Ilê Agboulá fugiram das incursões do aparelho de captura do Estado $^{5}$. A intendência (a polícia da época) agia determinada e incitada pelos discursos e agenciamentos da igreja católica e da sociedade mais ampla legitimada pela ciência e pela legislação da época.

A igreja acusava os candomblés de bruxaria, fetichismo, feitiçaria e rituais satânicos. A ciência de base positivista da época legitimou os discursos de que os membros do candomblé eram pessoas degeneradas, dementes, loucas ${ }^{6}$, doentes mentais, com os ditos casos de "patologias mentais" (as possessões) ou "'problemas psíquicos", oriundos dos saberes-poderes instituídos e edificados pela medicina clínica ${ }^{7}$ e, principalmente, da pisquiatria ${ }^{8}$, sendo, portanto, objetos de dessecamento científico.

A medicina clínica, ainda, acusava membros do candomblé de prática de falsa medicina, de exercício ilegal da medicina. A sociedade mais ampla construiu o discurso dos candomblés como coisa de bárbaros, selvagens, de atrasados, de raças inferiores (o racismo de estado'), coisa de 'negros".

Esses discursos e agenciamentos de conteúdo e de forma de expressão serviam como forma de legitimação das ações da intendência, das perseguições policiais, para que os candomblés fossem reprimidos, controlados, disciplinados, e, conseqüentemente, subjugados, dominados, "domesticados" e extintos. Um mal social que deveria ser extirpado, um "problema"' social que o Estado tinha por obrigação e dever eliminar, pois revelava todo o "atraso" da Bahia, inviabilizando o projeto de modernização e fragilizava o exercício do poder instituído.

O Estado, através de suas instituições (escolas, hospícios, manicômios, prisão, código penal, jurispludência, etc ...), deveria tornar os membros do candomblé "civilizados" eliminando traços de civilizações africanas dentro de uma parcela da sociedade que se queria européia.

Além desses fatores, os membros do culto aos Egum fugiam também da especulação imobiliária que se iniciava. Realizaram em 1941 a primeira

\footnotetext{
${ }^{5}$ DELEUZE, G.; GUATTARI, F. Mil Platôs: Capitalismo e esquizofrenia, vol.5. São Paulo: Ed. 34, 1997.

${ }^{6}$ FOUCAULT, Michel. História da Loucura. São Paulo: Perspectiva, 2007.

${ }^{7}$ FOUCAULT, Michel. Nascimento da clínica. Rio de Janeiro: Forense Universitária, 2004.

${ }^{8}$ FOUCAULT, Michel. Microfísica do Poder. Rio de Janeiro: Graal, 1979.

${ }^{9}$ FOUCAULT, Michel. Em Defesa da Sociedade. São Paulo: Martins Fontes, 2005.
} 
desterritorialização ${ }^{10}$ do templo localizado até então próxima à praia de Ponta de Areia, onde foi fundado.

Essa desterritorialização aconteceu em uma linha de fuga em direção à localidade do Barro Vermelho, onde reterritorializaram ${ }^{11}$ o terreiro, criando um outro território ${ }^{12}$ para os filhos de Agboulá (ver Figura 03).

Figura 03: Desterritorializações e reterritorializações do Omo Ilê Agboulá ao longo do século XX: 1940-1942 próxima a praia de Ponta de Areia; 1942-1960 no Barro

Vermelho; 1960-2020 no Bela Vista

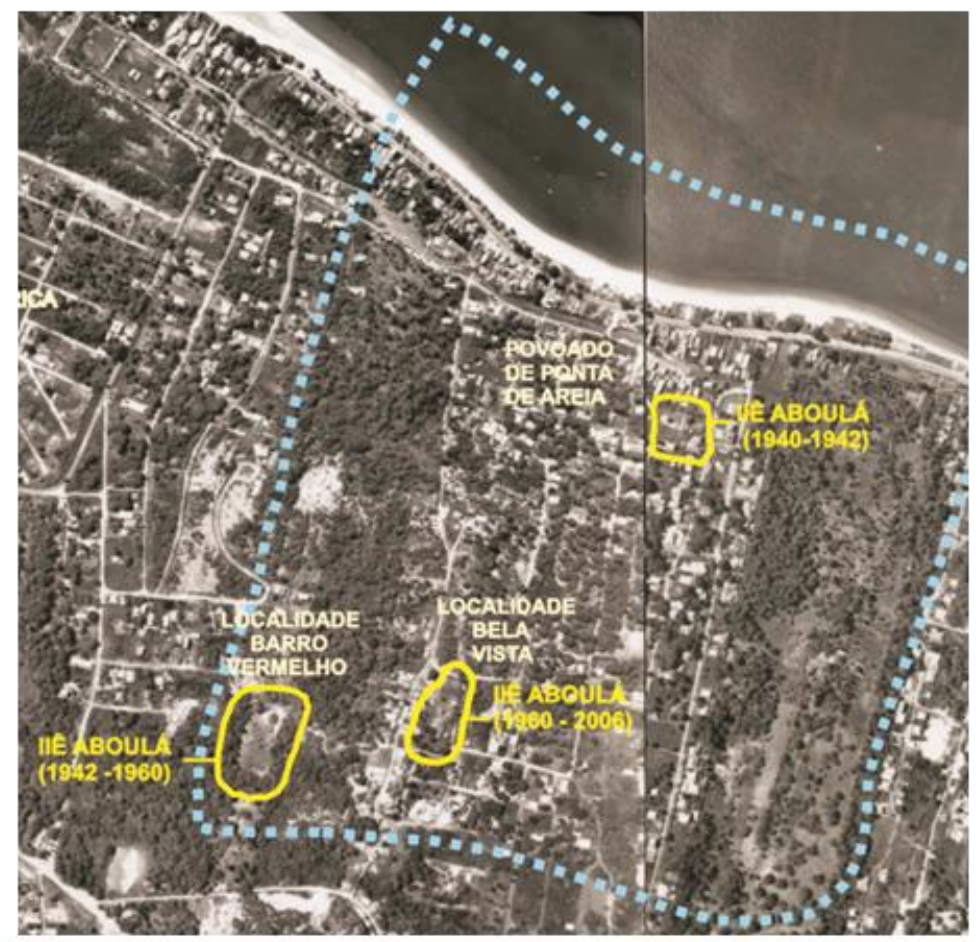

Fonte: VELAME, Fábio. 08/02/2006

Ainda hoje se encontram permanências, reminiscências e vestígios do terreiro original, próximo à igreja de Nossa Senhora das Candeias (local onde o terreiro foi

\footnotetext{
${ }^{10}$ Deleuze define desterritorialização como: 'A função de desterritorialização: D é o movimento pelo qual "se" abandona o território. É a operação da linha de fuga. " (DELEUZE; GUATT ARI, 1997, p. 224).

11 Deleuze define reterritorialização como: "'...$]$ valer pelo território perdido; com efeito, a reterritorialização pode ser feita sobre um ser, sobre um objeto, sobre um livro [...]. (DELEUZE; GUATTARI, 1997, p. 224).

${ }^{12}$ Deleuze define território como: 'O território é de fato um ato, que afeta os meios e os ritmos, que os "territorializa". O território é o produto de uma territorialização dos meios e ritmos[...] Precisamente há território a partir do momento em que componentes de meios param de ser direcionais para se tornarem dimensionais, quando eles param de ser funcionais para se tornarem expressivos [...] A marcação de um território é dimensional, mas não é uma medida, é um ritmo [...] A territorialização é o ato do ritmo tornado expressivo, ou dos componentes de meios tornados qualitativos". (DELEUZE; GUATTARI, 1997, p. 120).
} 
fundado), com a presença de elementos sagradas, com exceção de Iroco (Orixás árvore, divindade do tempo), que foi derrubado por um raio:

\begin{abstract}
Atualmente em frente à área encontra-se situada a igreja de Nossa Senhora das Candeias, padroeira de Ponta de Areia. Do lado esquerdo da capela ainda existe uma velha cajazeira (Spondias lutea), onde Ogum (orixá da guerra) era cultuado, e uma também antiga gameleira-branca (Ficus doliaria), a árvore sagrada do Orixá Iroco do tempo do terreiro de Eduardo. Não muito distante dali, encontra-se a casinha de Exu (orixá das encruzilhadas) que, de acordo com a tradição, não quis sair de onde se encontrava quando o terreiro foi transferido para outro local. Esses três marcos sagrados ali ainda são reverenciados e, de vez em quando, pode-se presenciar o sacrifício (matança) de um animal votivo (por exemplo, galo, galinha ou bode) a um daqueles orixás. Ao neto de Eduardo, de nome Manoel dos Santos (Baianinho), filho de Fernando dos Santos, Bamboxê, coube a responsabilidade de zelar pelo 'pé de Iroco". Assim, em época de Natal é ele obrigado a sacrificar ao menos um galo àquela divindade. Nessa ocasião, muitos dos descendentes de Eduardo ali se reúnem para participar da obrigação, respondendo as cantigas sagradas iniciadas ("tiradas") pelo seu oficiante e próprias daquela circunstância. (BRAGA, 1995, p. 28).
\end{abstract}

O Barro Vermelho (ver Fig. 03), era um lugar de difícil acesso, situava-se numa área de mata densa, distante da praia de Ponta de Areia e escondido pelo morro do Alto da Bela Vista; era perfeito para as necessidades do bom andamento do culto, ou seja, para a sua privacidade e segurança contra as investidas de curiosos e policiais. Sua visibilidade tinha que ser dificultada, sua localização tinha que torná-lo "invisível", para os forasteiros, pessoas estranhas à comunidade, e, principalmente, para as incursões policiais. O Barro Vermelho foi o local escolhido para a reterritorialização do templo, pois dificultava o acesso.

Devido a sua localização tática, membros da sociedade conseguiam se revezar na guarda do terreiro. Sempre ficava um membro de vigia no pé da ladeira do Alto da Bela Vista, notadamente no período das festas e obrigações. E, quando se aproximava alguém de fora, policiais, curiosos, pessoas estranhas à sociedade, moradores da Ilha que não pertenciam ao clã da família de Paula ou ao culto, era imediatamente comunicado aos demais, que constituíam uma rede de comunicação, informação e proteção. Rapidamente as pessoas presentes no Omo Ilê Agboulá sabiam o que estava acontecendo e tinham tempo suficiente para tomar as decisões e medidas que achavam mais adequadas para a situação:

Antigamente agente tinha que se esconder e fugir para sobreviver então éramos muito fechados e desconfiados, esta história de terreiro de Egum, está história de 
um lugar muito perigoso, onde a morte e os mortos rondavam, toda está fama do terreiro de Babá foi criada como forma de sobrevivência, para evitar curiosos, pessoas estranhas do culto, pois ainda tinha a perseguição da policia, investidas policiais, a pressão da Igreja, aí a gente, os nossos mais velhos, os ancestrais, criaram essas histórias para manter as pessoas afastadas, tinha até uma maneira muito especifica de lidar com os estranhos e forasteiros, ficava sempre alguém no pé da ladeira que dava para o Barro Vermelho e quando alguém de fora se aproximava ele mandava o recado e o recado ia de casa em casa pelos membros do culto, ou ele ia rápido até o terreiro e avisava, então o pessoal tinha tempo de fechar a casa e sai, quando os estranhos chegavam lá tava tudo fechado, não encontravam ninguém e assim foi indo [...] (informação verbal) ${ }^{13}$.

A partir dos anos de 1960, com a intensificação da escolha da Ilha de Itaparica como um local de balneário por alguns estratos sociais da cidade de Salvador, e, principalmente mais tarde, nos anos de 1970, pela ação direta do governo do estado com: os planejamentos sistemáticos da $\operatorname{CONDER}^{14}$; a subseqüente implantação de infra-estrutura como o sistema Ferry-boat, a BA-001, que cruza a ilha de ponta a ponta e a liga ao continente através da ponte do Funil; a implantação de construções e serviços urbanos (hospitais, delegacias, postos de saúde, escolas, estradas, abastecimento de água...), viabilizou-se e potencializou-se a especulação imobiliária em toda a ilha. Assim foi o ocorrido em Ponta de Areia, com a subseqüente expansão e crescimento do povoado, alterando-se drasticamente os meios de subsistência, as relações e os modos de vida da sociedade de culto aos Egum, que até então era uma pequena vila de pescadores. Foram geradas novas formas de trabalho, lutas pela sobrevivência e novas relações sociais, religiosas e domésticas entre os membros da sociedade de culto aos ancestrais:

$\mathrm{Na}$ verdade, grande parte da população permanente de Ponta de Areia, excetuando os poucos pescadores locais, é constituída de desempregados que vivem de biscates, prestando serviços aos veranistas, trabalhando sob regime de empreitada em eventuais construções ou ainda como diaristas em roças da vizinhança. Esse quadro só é compensado com as atividades da pesca artesanal e da vendagem do peixe aos intermediários, que o transportam para os mercados de Salvador.[...] Em situações de crise financeira, especialmente nos períodos de inverno, com a ausência de veranistas, a mulher passa a ter uma participação muito importante na obtenção do alimento básico, indispensável ao sustento da família. Nessas ocasiões, cessam, praticamente todas as possibilidades de trabalho remunerado para a população masculina. A comunidade passa, então, a

\footnotetext{
${ }^{13}$ Informação fornecida por Balbino Daniel de Paula, Alabá do Omo Ilê Agboulá em Ponta de Areia no município de Itaparica em 08 de fevereiro de 2006.

14 Tendência que se consolidou com o Plano Diretor da Ilha de Itaparica de 1978, da CONDER Companhia de Desenvolvimento da Região Metropolitana de Salvador, que retoma alguns pontos do Plano de Itaparica de Peltier de Queiroz. O Plano Diretor de 1978 considera a Ilha de Itaparica como uma área de balneário, uma opção de lazer, e diversão para a população da cidade de Salvador, propondo equipamentos urbanos, e infra-estrutura para viabilizar este cenário para a Ilha de Itaparica.
} 
depender quase exclusivamente das pescarias artesanais, realizadas ao longo de suas praias. Delineia-se, desta maneira, um estado de pauperização cíclica da população, que se vê obrigada a recorrer a toda espécie de expediente para conseguir víveres assenciais à subsistência, dependendo, para isso, da efetiva participação das mulheres e crianças como força de trabalho. [...] Em ponta de Areia, as crianças ajudam igualmente as mulheres na ampliação do orçamento doméstico, realizando todo tipo de trabalho remunerado ou encarregando-se da venda de produtos confeccionados em suas casas. [...] Quando estão vendendo esses produtos ou realizando um trabalho remunerado, as crianças se encarregam de diferentes tarefas domésticas, o que possibilita às mulheres realizarem certas atividades lucrativas, como lavar roupa de ganho, carregar água para moradores em melhor situação financeira ou, então, venderem elas próprias suas mercadorias. (BRAGA, 1995, p. 67).

A situação se mantém até hoje, como se pode notar pela informação de Balbino de Paula:

Já tem um tempo isto, aqui era uma vila de pescadores, antigamente tinha muitos pescadores, a maioria dos Ojés eram pescadores, hoje você conta nos dedos, só tem uns poucos Ojés pescadores, ai depois do Ferry-boat e a pista de asfalto começou a aparecer aposentados e famílias querendo comprar casas e terrenos para morar ou fazer casa de veraneio, as pessoas aqui eram muito simples, a ai começaram a vender suas casas e pedaços de terra que tinham para comprar uma geladeira, um fogão, uma televisão, para ter pouco mais de conforto, e se mudaram para mais perto do terreiro de Babá, no Alto do Bela Vista, ficando mais perto dele para não ter que subir a ladeira nas festas ou quando iam fazer alguma limpeza espiritual, mas como disse eles venderam suas propriedades para ter uma vida com um pouco de conforto, uma oportunidade que surgiu, e eles construíram suas casas lá no Bela Vista. (informação verbal) ${ }^{15}$.

Novamente o Omo Ilê Agboulá e seus membros tiveram de se mudar, em virtude de dois loteamentos que surgiram em sua proximidade para atender à classe média, que buscava lotes para construir casas de veraneio; de aposentados que procuravam um estilo de vida mais bucólico e tranqüilo; de pessoas que buscavam moradia, pois trabalhavam em outros municípios vizinhos a Itaparica:

Mais recentemente, Ponta de Areia vem sendo assediada por aposentados, atraídos, sem dúvida, pela beleza das praias, pela cordialidade dos habitantes e, seguramente, pelo privilégio de poder viver numa comunidade onde são praticamente os únicos a dispor de renda fixa mensal, advinha de suas aposentadorias. (BRAGA, 1995, p. 51).

Devido a grande especulação imobiliária que campeia as terras da ilha de Itaparica, a família Daniel de Paula que outrora residia à beira da praia, está sendo "empurrada" para o interior da ilha, deixando aquela área, para se reagrupar nas encostas situadas entre Ponta de Areia propriamente dita e o lugar denominado Bela Vista onde se encontra o terreiro-de-egum. Essa forçada

15 Informação fornecida por Balbino Daniel de Paula, Alabá do Omo Ilê Aboulá em Ponta de Areia no município de Itaparica, em 08 de fevereiro de 2006. 
relocação espacial da população nativa para o local onde está o terreiro de Babá Aboulá, possibilitou o reagrupamento daquela família em torno da comunidade religiosa que se beneficia de maior assiduidade às festas públicas, reanimando cada vez mais a sua vida religiosa. (BRAGA, 1995, p. 101).

Estes loteamentos de classe média cresceram invadindo a área da mata sagrada do Omo Ilê Agboulá no Barro Vermelho, chegando até mesmo a fonte sagrada de Oxum (divindade nagô das águas doces dos rios e lagoas), a ser privatizada, pois ela se encontrava em um terreno que foi vendido a terceiros, que passaram a proibir o seu acesso para os membros do culto:

Porque foram abertos loteamentos próximo ao Barro Vermelho, abriram vários lotes, e aí agente perdeu a privacidade de fazer os nossos cultos, de fazer as nossas coisas [...], sempre tinha alguém passando, ou olhando, ai não dava pra fazer as nossas atividades, foi quando a finada Mãe Senhora, que era a mãe de Didi e ocupava o cargo de Iá Ebé comprou o terreno no Bela Vista, mas agente perdeu a fonte sagrada, o terreno onde fica a fonte foi comprado e o dono deixava agente ir lá pegar a água para os rituais, para as nossas necessidades, mas o dono novo, que comprou do outro, não deixa de forma nenhuma agente entrar lá, e era um lugar não só importante pro culto mas também que faz parte da nossa história de vida, quando era criança as vezes Babá aparecia e agente corria pra casa, ele pegava as roupas, ou agente ia pra fonte e quando chegava lá tinham coisas das roupas de Babá ai agente voltava pra casa nem se atrevia a entrar na água (informação verbal) ${ }^{16}$.

Várias são as histórias referentes à fonte sagrada de Oxum. Os Ojés, sacerdotes do culto aos Egum, contam que, quando eram crianças, iam se banhar na fonte sempre atentos, pois os Egum podiam aparecer a qualquer momento, quando apareciam, todos saíam correndo para o mato, a se esconder para não apanhar dos Egum; outras vezes, os Egum roubava as roupas dos banhistas, castigando aqueles que iam tomar banho na fonte sagrada sem permissão dos mais velhos, fazendo com que eles voltassem nus para casa; em uma outra ocasião, ao irem ao local da fonte encontravam contas, espelhos, elementos que compõem a roupa dos Egum, dando sinal de que ele tinha passado por lá e de que se encontrava na redondeza e ninguém se atrevia a entrar na água, etc...Os membros da sociedade não se conformam de não terem mais acesso às águas que contêm o axé que sai da terra, de não terem mais o direito ao acesso a sua fonte sagrada de Oxum. Ressentem-se, lamentam-se e reclamam do novo proprietário que impede a sociedade de utilizar a fontes para os seus rituais.

\footnotetext{
${ }^{16}$ Informação fornecida por Balbino Daniel de Paula, Alabá do Omo Ilê Aboulá em Ponta de Areia no município de Itaparica, em 08 de fevereiro de 2006.
} 
Em virtude destes loteamentos, além de perder parte da mata sagrada e a fonte sagrada de Oxum, o terreiro do Omo Ilê Aboulá no Barro Vermelho perdeu também a privacidade para realização de seus rituais secretos e até de suas festas públicas. Na primeira metade dos anos de 1960, Mãe Senhora, a Iá Ebé ${ }^{17}$ do culto aos Egum, comprou um terreno na localidade do Alto da Bela Vista, fazendo a sua mudança; ali o Omo Ilê Agboulá se encontra até hoje (ver Figura 04).

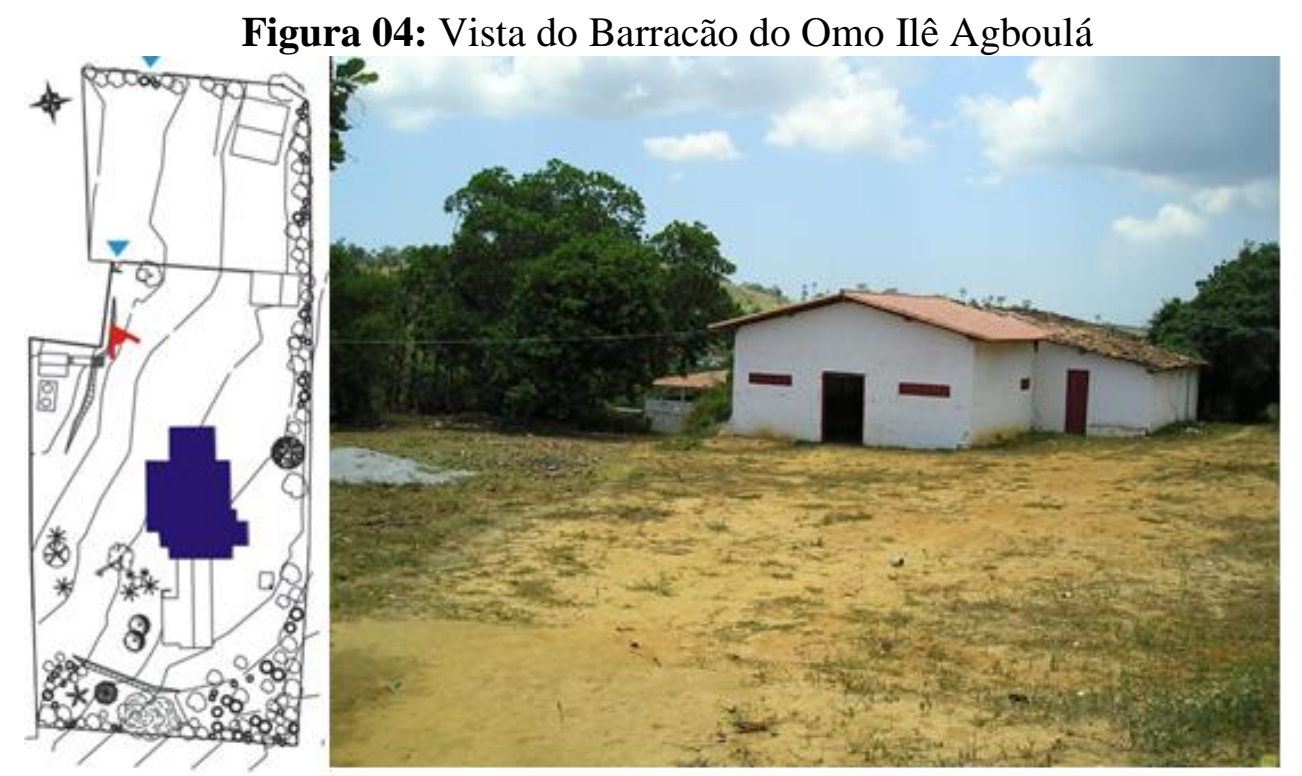

Fonte: VELAME, Fábio M. Data: 08/02/2006.

Novamente, os membros do culto aos ancestrais desterritorializaram o templo do Omo Ilê Agboulá, localizado naquele momento no Barro Vermelho, em uma outra linha de fuga, mas dessa vez em direção ao Alto do Bela Vista, onde o templo e os membros da sociedade dos Egum se reterritorializaram, criando um outro território. Hoje o terreiro se encontra no lugar denominado de Bela Vista. Segundo Laércio dos Santos, Alabá do Ilê Babá Onilá no Rio de Janeiro e Ojé Abá do Omo Ilê Aboulá:

Chama-se Bela Vista, mais a casa atende de babadolua que é o terreiro que é o dono da casa, eu nunca perdi festa aqui desde quando eu não tinha casa de candomblé eu vivia em São Paulo, sempre andava nas minhas obrigação de dia 6 de janeiro eu tava aqui, dia 8 de setembro eu tava aqui cedo acompanhado meus tios, meus primo, meus irmãos que deus já levou tudo, e sempre to aqui como estou aqui hoje porque se eu não controlo, eu tava aqui ajudando meu irmão tirando alguma coisa de mim pra ajudar, que na sua casa não tem nada e eu ajudando a festa de omolocotum vai sair e no dia 6 de janeiro nós

17 A Iá Ebé é o mais alto cargo feminino da hierarquia do culto aos Egum, é a mãe da sociedade e responsável por todas as atividades relativas aos Orixás. 


\section{O.}

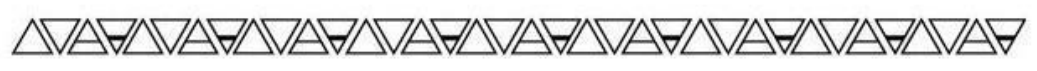

começamos a festa no dia 5 e fomos até o dia 9 foi três dias de festa o pessoal comeu eu dei comida pro povo, teve tudo, bandeira agora dia 20 comprei fogos tudo quer dizer, eu estou aqui né tira nada daqui eu to aqui ajudando qualquer coisa aqui pra casa não cair. (CAETANO; SOARES; VELAME, 2006).

Novamente este terreiro, lutando pela sua sobrevivência, buscou um outro lugar, onde pudesse cuidar, zelar, reverenciar e invocar seus ancestrais. Um lugar onde, mais uma vez, pudesse erguer um outro templo, com outras construções e outros espaços, mas sendo sempre o 'mesmo"' Omo Ilê Agboulá. Segundo Agostinho dos Santos, Ojé Abá do Omo Ilê Agboulá:

Era Eduardo Daniel de Paula morreu com cento e poucos anos foi o fundador desse terreiro lá embaixo lá no fundo da igreja e depois mudou para o barro vermelho mais a finada a senhora Maria Bibiana do Espírito Santo pediu a babolua que na época não tinha ferry boat era navio então ela vinha no navio soltava em Itaparica e finado Caetano que sempre nas festas de babolua dava coisa dava carne pra dar comida ao pessoal ela que botava lá no jipe e trazia até ali ao barro branco então ela subia então ela pedindo já to ficando velha e cansada e pediu pra babolua se ele dava o consentimento dela comprar um terreno pra fazer a casa dele mais perto ai ele chegou e disse que dava porque ela disse que ficava cansada então naquela época ela subia aqui pela ponta do barro vinha de tarde com a fresquinha e só tinha um pedacinho de ladeira como é esse pedaço e a ladeira de lá era maior aí babolua deu consentimento a ela então ela comprou esse terreno e deu pra babolua [...] Eu nasci nessa casa eu vim de minha mãe de meu avô minha avó meu pai eu vim dentro da magia aqui da casa e se furar aqui o sangue é de seu Eduardo Daniel de Paula. (CAETANO; SOARES; VELAME, 2006).

No bairro do Alto da Bela Vista, em Ponta de Areia, no Omo Ilê Agboulá residem algumas famílias, cuja maioria é formada por parentes e membros da sociedade de culto aos Egum. Constitui uma comunidade, uma família extensa, ligados por laços consangüíneos e religiosos, descendentes de Eduardo Daniel de Paula, segundo Agostinho dos Santos, Ojé Abá do Omo Ilê Agboulá:

Então naquela época, o pessoal a minha avó era que fazia os partos daqui, mais era todo mundo parente, por que na família todo mundo era parente entendeu? Era filha, era sobrinha, neto então era assim, então ele e Laércio já eram um pouco mais velho do que eu, então ele alcançou mais coisa do que eu, por que quando me aprofundei, por que eu trabalhei em Salvador e depois que eu vim pra cá, e quando me aprofundei na seita e comecei a entrar nas obrigações eu ainda peguei meu tio Antonio que era um veterano e eu já to com quase trinta e poucos anos de oje já [...] Meu nome aqui dentro do babolua é oluidê, e o meu de batismo é Agostinho dos Santos, eu sou filho de dona Ninha de Paula, e filho de Fernando Vitoriano dos Santos eu sou filho da primeira irakekê no tempo da Moreira do Barro Vermelho, e ela morreu aqui nesse terreiro aqui, então sou filho dela, eu Laércio, Domingos mais uns 4 irmão que morreram, morreu 
Domingos o mais velho, morreu Jaime que também era oje, morreu Sarafim que era oje também, e morreu Benicio que também era oje, e o meu irmão caçula morreu ali tocando tabaque ali que hoje é egum que se chama omoilê, essa é a minha família então nós não escreveu com Daniel de Paula por causa de meu pai mais a gente tem Daniel de Paula de minha mãe. (CAETANO; SOARES; VELAME, 2006).

A partir dos anos 2000 diversos templos de culto neopetencostais instalaram-se no Alto do Bela Vista, ao redor do Omo Ilê Agboulá, passando a pressionar o templo, concorrendo com alto falantes com cantigas dos cultos neopetencostais com os rituais e cantigas de Egum nos dias de festa internos do Omo Ilê Agboulá, além da realização de investidas e ações de doutrinação dos membros do culto aos Egum, assim como, a realização de um conjunto de ações de intolerância religiosa e de racismo no território do bairro. Em função desses fatos a comunidade veio paulatinamente, lutando junto aos órgãos do patrimônio como a Fundação Cultural Palmares - FCP e o Instituto do Patrimônio Histórico e Artístico Nacional - IPHAN para o tombamento nacional do terreiro e estabelecimento de diretrizes de preservação do seu entorno imediato, como forma de resistência e sobrevivência do culto. Após muita e luta e persistência da comunidade de culto aos Egum, em novembro de 2015 o conselho consultivo do IPHAN tombou, por unanimidade, o Omo Ilê Agboulá como Patrimônio Cultural do Brasil.

Mas a resistência cotidiana aos cultos neopetencostais continua na atualidade através das festividades públicas e urbanas da comunidade de culto aos Egum. Nas datas importantes do calendário litúrgico e nas obrigações, boa parte da sociedade, mesmo os que moram em Salvador e outros estados, para lá geralmente voltam, permanecendo no povoado por vários dias, fortalecendo os laços da sociedade, recebendo as bênçãos, os conselhos e as repreensões dos Babás, estabelecendo enfim todo um processo de continuidade da tradição e de sua singularidade cultural. Daí, a grande importância do culto aos ancestrais no povoado, pois é um elemento de coesão grupal, de elo entre o passado e o presente. Esses diversos lugares sagrados espalhados pelo povoado de Ponta de Areia usados no cotidiano, que constituem uma rede do sagrado pela cidade, são potencializados durante o ciclo da festa das águas, tendo como ápice a festa dos presentes a Iemanjá no dia 02 de fevereiro. A festa dos presentes é uma festa das divindades das águas Iemanjá, Oxum e Olokum, que ocorre todos os anos no dia 02 de fevereiro no Ilê Omo Agboulá em Itaparica. 


\section{3 - A FESTA DOS PRESENTES E A RESISTÊNCIA DOS FILHOS DE}

\section{AGBOULÁ}

A festa das águas constitui-se em um processo de resistência dos membros do culto aos Egum a cidade racializada, combate historicamente os processos de expulsão da polícia nos anos 1940, a expulsão do mercado imobiliário dos anos de 1960-80, e a ação de expulsão dos cultos neo-petencostais da atualidade. O ritual começa logo cedo, pela manhã, através da missa na igreja de Nossa Senhora das Candeias, que marca o início dos preparativos da festa das águas no Omo Ilê Agboulá, ocorrendo uma utilização por parte da sociedade de culto aos Egum do espaço e tempo sagrado católico para a concretização de seus rituais afro-brasileiros. Depois dos preparativos e rituais secretos da sociedade (sacrifícios de animais votivos, oferendas de comidas com as folhas e ervas sagradas retiradas da mata sagrada da antiga morada do Omo Ilê Agboulá no Barro Vermelho, presentes aos Egum, o Padê...), por volta das três horas da tarde, começam a chegar os membros femininos da sociedade vistosamente postas com suas guias e belas batas com rendas.

Quando começam a soar os atabaques e os agogôs com músicas para as divindades e depois para os Egum, nessa ocasião as mulheres dirigem-se para o espaço semi-público do barracão onde fazem as danças propiciatórias, tal como na festa da Bandeira e nas demais festas dos Egum do calendário litúrgico da casa. O som dos atabaques, agogôs, as cantigas das Erelu formam um conjunto harmonioso que enche de axé o espaço do barracão, todos cantam e se entusiasmam, criando uma atmosfera sagrada. Logo é colocado no chão do espaço semi-público do barracão um Alá, um pano branco sagrado, e, um a um, os presentes, "uniformizados" em jarros delicadamente decorados com panos coloridos, bordados e encimados por flores são trazidos e depositados pelos Ojé para que possam ser abençoados pelos Egum, num número certo de presentes conforme os preceitos do culto.

Estes presentes são trazidos ao terreiro pelos membros do culto, filhos e filhas-desanto, adeptos do candomblé e visitas. São entregues aos Ojés que os levam, os depositam em vasos e os preparam dentro do Lessém (a casa do segredo), onde eles passam por rituais de purificação e sacralização específicos secretos da sociedade, recebendo o axé da casa e dos Egum. Os vasos passam a ser peças de uma corrente de 
axé, que se iniciará dentro do terreiro e ganhará as ruas do povoado. Esses vasos ${ }^{18}$ são feitos de cerâmica, sua matéria é retirada da terra, retirada do seio de Onilê (Orixás da terra), uma dádiva dada por Onilê aos mortais, aos seres que habitam o mundo.

Estes, com o trabalho de suas mãos, moldam os vasos e, com seu axé, lhe dão forma, para que possam receber, acolher e reter, em seu vazio, as flores, os presentes, a água sagrada e o axé de Babá. Os vasos recebem e acolhem as belas e ricas flores trazidas pelos seus filhos para Iemanjá, decoradas com singelos panos coloridos e bordados. Estas flores são delicadamente dispostas dentro dos vasos brancos que espalham, envolvem e embriagam, com seu aroma e perfume, o espaço do templo, levando os mortais presentes a sentirem e experimentarem o cheiro divino do Orum. Os vasos recebem e acolhem uma água sagrada que caí como dádiva do céu, vindas do Orum com as bênçãos de Oxalá (Orixás da criação), que, com o seu Opaxorô faz balançar as nuvens, ordenando-lhes que derramem sobre a terra, o Aiê, a fartura e a vida. As águas adentram as entranhas da terra de Onilê, que acolhe cada gota e a faz aflorar em axé nas plantas, nas matas verdes, e que acalanta e sacia a sede dos filhos de Agboulá. A água brota da terra de Onilê através da fonte de Oxum localizada na antiga morada do Omo Ilê Agboulá no Barro Vermelho, proibida agora aos filhos de Agboulá.

$\mathrm{Na}$ fonte de Oxum, perduram todas as pedras e os segredos velados da terra, que guarda a chuva do céu. Na água da fonte de Oxum, acontece o casamento entre céu e terra, que perdura e frutifica no axé presente no abrir das flores doadas como presentes; no crescimento do milho branco com que se faz o acaçá; nas folhas rituais das plantas sagradas.

Os vasos recebem e acolhem o axé dos Babás, as suas bênçãos e o encaminhamento dos pedidos, desejos e as esperanças dos mortais a Iemanjá, pois a rainha do mar só atenderá se os Babás os recomendar, porque a eles ela ouvirá e realizará as súplicas dos seus filhos, dos bons filhos que os zelam e os cuidam. Os vasos transformam-se em um altar que se move em uma corrente de axé pelas ruas do povoado em direção ao mar, à morada de Iemanjá, tendo como pernas os corpos dos filhos de Agboulá indo em direção aos barcos no mar. No lugar das oferendas no mar, os vasos tornam-se a doação à Iemanjá, que, ao vazar, o vaso vive como doação. Vazar torna-se oferecer, sacrificar e, desse modo, doar, realizar uma oferta sacrificial. Os vasos doam presentes consagrados. Na doação da vaza dos vasos, vivem os pedidos e as

${ }^{18}$ HEIDEGGER, Martin. Ensaios e Conferências. Vozes: São Paulo, 2006. 
esperanças dos mortais, os filhos de Agboulá; como encaminhamento e solicitação, vivem os imortais, os Egum; como oferendas, vive o divino, Iemanjá, que recebe de volta e em retribuição a doação de suas dádivas. Na doação da vaza do vaso, vive, cada um a sua maneira, em conjunto, de forma simultânea e coexistente, o jogo em espelho do mundo entre terra, céu, mortais, imortais e divinos. A doação da vaza do vaso doa à medida que deixa morar esse jogo em espelho do mundo. Os vasos doam a Iemanjá, em seus braços de mar, o trabalho cuidadoso dos mortais, o axé e as recomendações dos Egum, as oferendas em presentes e as esperanças dos filhos de Agboulá.

Soam os atabaques chamando os ancestrais e eles entram pela porta da frente ou pela porta lateral do barracão cheio em meio a grande alegria e júbilo. Babá Nilewo e Babá Amoro Mi Todo, com seus opás (indumentárias de Egum), dançam, pedem as suas músicas, abençoam os seus descendentes, perguntam pelas mulheres mais velhas da casa. Estas com enorme alegria respondem, pedindo imediatamente as suas bênçãos. Aqueles prontamente lhes dão, depois perguntam pelos seus familiares e todos eles lhes pedem a bênção. Depois de dançarem, eles abençoam a todos e abençoam os presentes, balançando o seu banté em direção aos presentes. Eles dão a volta várias vezes em torno dos presentes para que todos eles recebam o seu axé, as suas bênçãos, para que Iemanjá receba com satisfação cada um dos presentes e atenda a cada um dos pedidos ali depositados. Em seguida, todos saem do barracão. Nesse momento, saem os Alabés seguidos pela fila da hierarquia feminina das mais velhas às mais novas, carregando os jarros na cabeça, organizando-se e concentrando-se para o cortejo que irá se iniciar. Cantam então para os Egum que retornaram ao Ilê Auô, a casa do segredo.

$\mathrm{O}$ primeiro presente, que está enfeitado com pano branco, que vai à frente do cortejo, é dedicado a Oxalá; o segundo, que está envolto com o pano azul, é de Iemanjá e o terceiro, que está arrumado com um pano amarelo, é dedicado a Oxum. Depois que todas enfileiram-se, formando a corrente de axé, tem início o trajeto do cortejo saindo do terreiro pelo seu espaço sagrado público. Sai o cortejo pelas ruas do bairro Bela Vista (ver Figura 05), onde se encontra o terreiro, trazendo à frente o Alabá, os Ojés Abá com os seus agogôs e os Alabés com os atabaques, seguidos por trinta e poucas mulheres, guardadas e zeladas nas laterais por outros Ojés. O cortejo cria uma corrente móvel de energia que sai do som dos atabaques, se funde com os cantos das mulheres e com os presentes a Iemanjá, criando um fluxo de axé pelas ruas da cidade. 
Fig. 05: Trajeto do cortejo dos membros do culto aos Egum na festa dos presentes, $02 / 02$, em uma corrente de axé pelas ruas

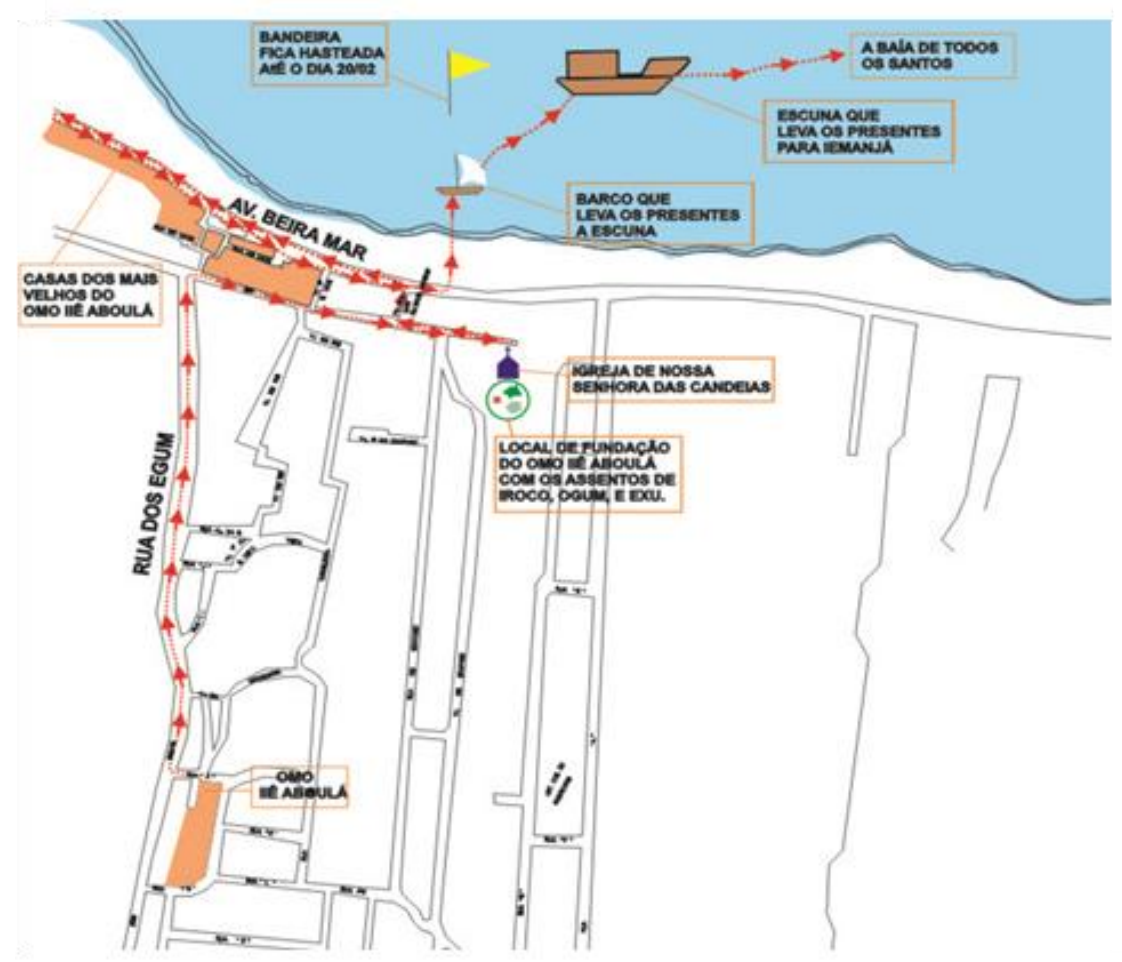

Fonte: VELAME, Fábio M. Data: 08/02/2006.

O fluxo de axé criado pela corrente dos filhos e filhas de Agboulá (ver Figura 06) não deve ser quebrado por ninguém, porque, se alguém quebrá-lo ao cruzá-la, um pedido à rainha do mar deixa de ser atendido, "capturando" o axé da corrente, "capturando" um pedido, sendo proibidas, portanto, as pessoas de atravessarem de um lado ao outro o cortejo. O cortejo rompe as ruas do Bela Vista, descendo a rua dos Egum, criando um momento único, quando o candomblé, notadamente o culto aos Egum, toma com força e quantidade de membros as ruas de Ponta de Areia. 
Figura 06: Início do cortejo composto pela corrente de axé formada pelos membros do culto aos Egum.

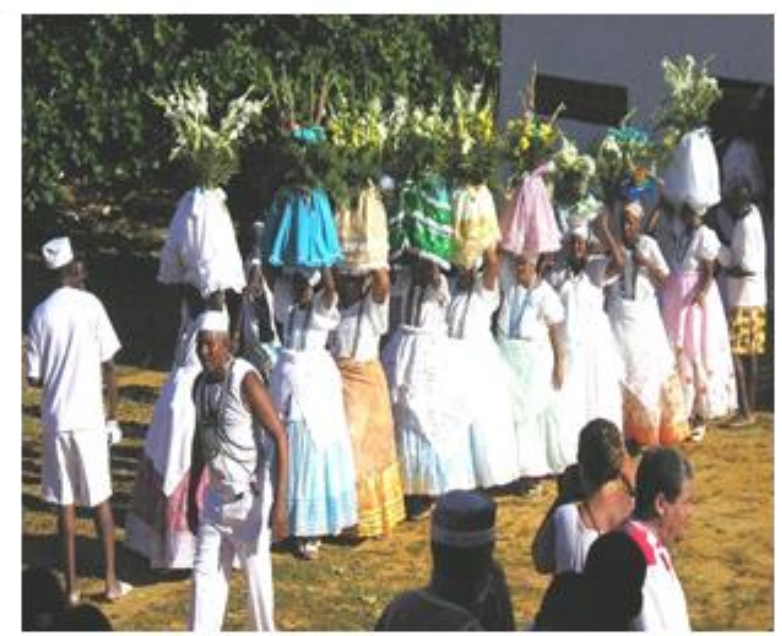

Fonte: VELAME, Fábio M. Data: 02/02/2006.

O cortejo desterritorializa o Omo Ilê Agboulá e o reterritorializa sobre a cidade, levando o espaço e tempo sagrado do terreiro para o profano das ruas do povoado, onde o culto aos Egum retoma, com ímpeto, toda a cidade através do fluxo de axé da corrente. A corrente transforma, momentaneamente, em sagrada, cada viela, rua e praça no instante em que por estas passa, o tempo sagrado do ritual acontece nos espaços profanos de Ponta de Areia. Cada presente possui a sua singularidade (ver Figura 07), cada presente é único.

Os presentes vêm cheios de detalhes, caprichosamente montados, arrumados, trazendo espelhos, sabonetes, perfumes, pentes, bijuterias, bonecos, flores e esculturas de Iemanjá em sua forma popular latinizada de sereia. Cada presente leva histórias, mas não qualquer história, e sim histórias de vidas. Os presentes também levam pedidos, ao longo do trajeto, muitas pessoas querem depositar os seus e oferecem aos Ojés flores e perfumes. Pedem que sejam colocados nos vasos, para que Iemanjá possa atender. Os presentes carregam os sonhos das pessoas por um trabalho, um emprego, por saúde ou amor. Os presentes carregam as esperanças das pessoas. 


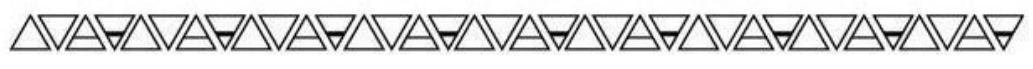

Figura 07: Cortejo da sociedade de culto aos Egum se dirigindo em direção da Igreja de Nossa Senhora das Candeias

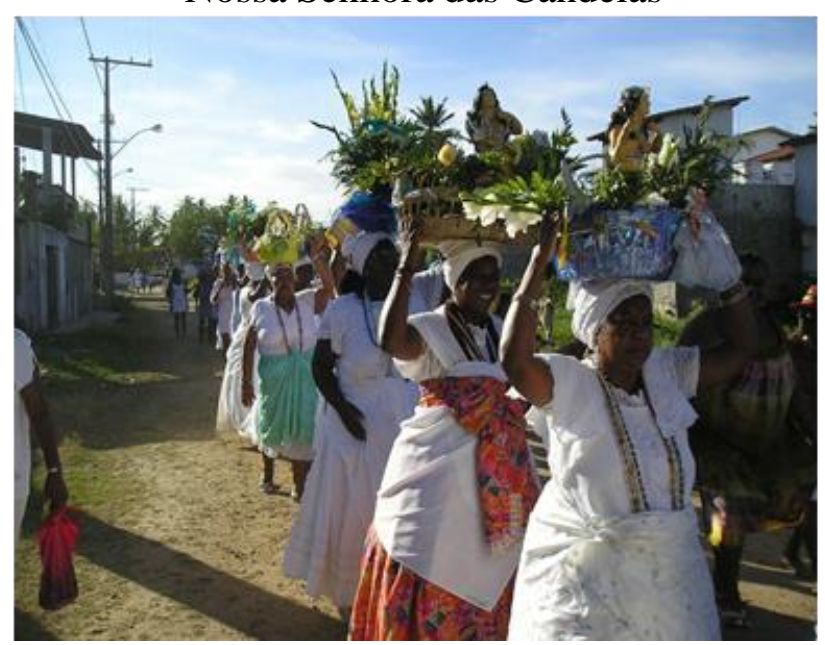

Fonte: VELAME, Fabio M. Data: 02/02/2006.

O cortejo chega a Ponta de Areia e segue o seu trajeto histórico, que passa de geração em geração desde a reconstrução do Omo Ilê Agboulá no alto do Bela Vista, quando os filhos de Agboulá conquistam e revelam que são os fundadores de Ponta de Areia, que as ruas e praças também lhes pertencem. Num primeiro momento o cortejo segue para a Igreja de Nossa Senhora das Candeias, onde nos fundos foi fundado o Ilé Omo Agboulá por Eduardo Daniel de Paula (ver Figura 08). Os membros do cortejo, ao chegarem ao largo da igreja de Nossa Senhora das Candeias, veneram, reverênciam, cantam músicas e saúdam os ancestrais que fundaram o terreiro, fazendo a volta nesse largo e seguindo para a Avenida Beira Mar de Ponta de Areia. 
Figura 08: O cortejo da sociedade de culto aos Egum dá à volta em frente à Igreja de Nossa Senhora das Candeias reverenciando os ancestrais e dirige-se em direção a Avenida Beira Mar.

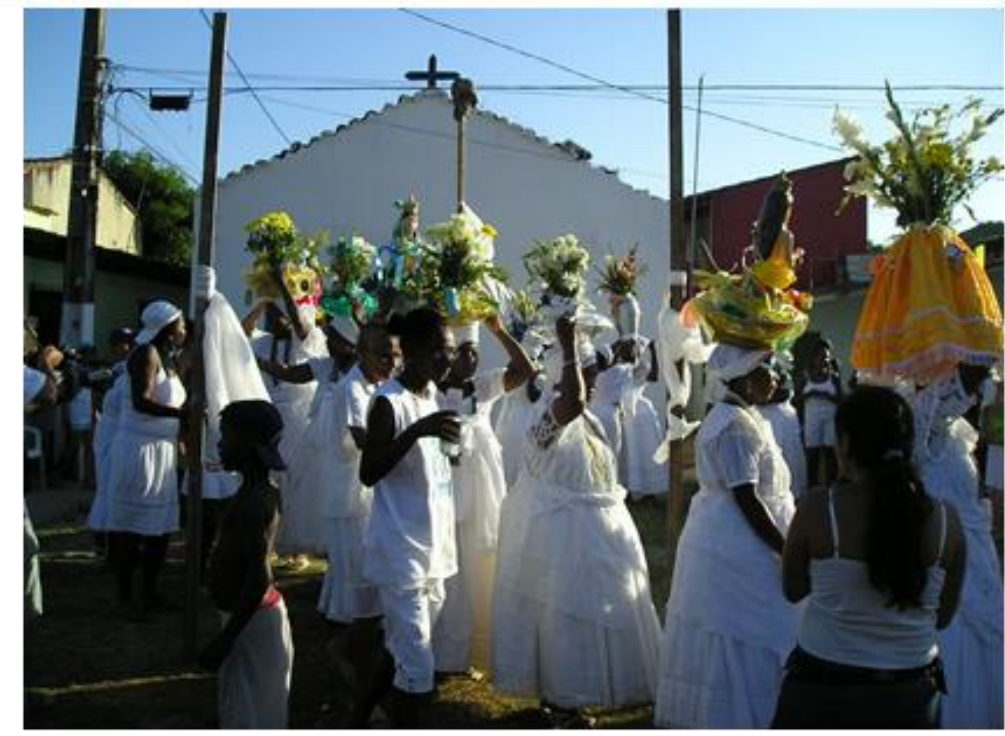

Fonte: VELAME, Fábio M. Data: 02/02/2007.

O cortejo desfila pelas ruas do povoado de Ponta de Areia em direção à Avenida Beira Mar, sempre cantando ao som dos atabaques e foguetes. As ruas, as varandas e janelas das casas são tomadas por moradores, veranistas e turistas, aplaudindo o cortejo. Por onde passa o cortejo, as pessoas juntam-se a ele. A cidade se enfeita com bandeirolas brancas, que enfeitam as ruas e praças.

O cortejo se desloca para a Avenida Beira Mar para ir ao encontro das casas dos membros mais antigos da sociedade, dos 'mais velhos', e da residência do antigo Alabá, Domingos. Isso ocorre em sinal de respeito aos "mais velhos"' e para mostrar a realização do cortejo ritual dentro dos preceitos para aqueles que contribuíram financeiramente ou com trabalho para a sua realização. O encontro é uma comunhão pública, uma "prestação de contas públicas" do andamento ritual para aqueles cuja idade e condições físicas impossibilitam de participar efetivamente do cortejo ou de ir para o terreiro no início da festa para receber a bênção e o axé de Babá devido a idade avançada.

O cortejo passa em frente das casas dos "mais velhos"' da sociedade no limite de Ponta de Areia, onde fazem a volta para irem em direção à praia. O cortejo passa saudando e reverenciando a todos os "mais velhos" que estão sentados em suas 
cadeiras no passeio ou nas varandas de suas casas. Todos eles mergulham em uma grande alegria ao verem a tradição que receberam de seus pais e avôs continuando nas mãos dos mais novos, dos seus filhos e netos. Com grande júbilo, aplaudem o cortejo dos presentes, extremamente satisfeitos com o rigor do ritual. O cortejo dirige-se para a praia, fechando o percurso simbólico na sua etapa terrestre pelas ruas do Bela Vista e de Ponta de Areia (ver Figura 09), onde fazem as últimas cantigas em terra sobre a areia da praia.

Fig. 09: O cortejo, depois de saudar os mais velhos vai em direção a praia

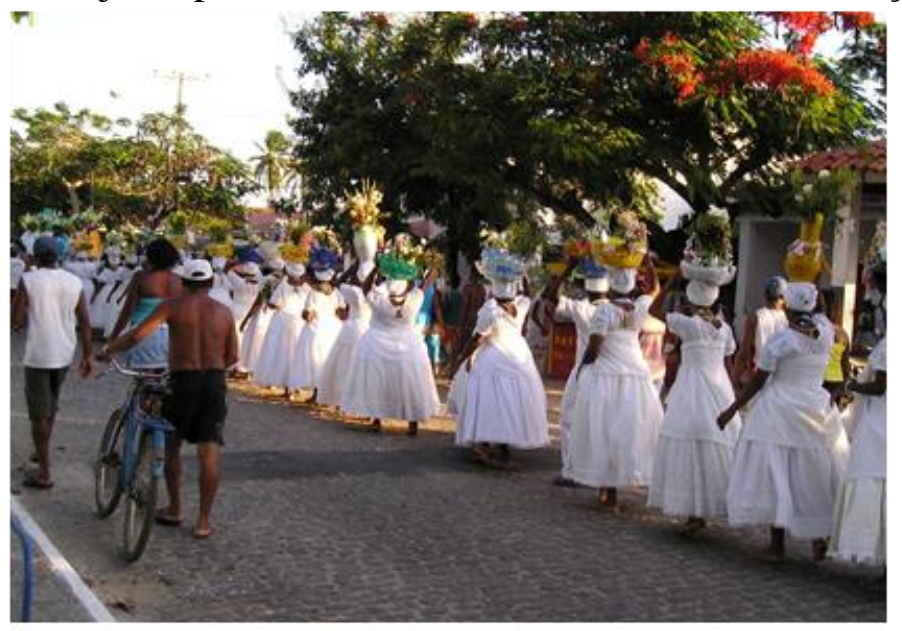

Fonte: VELAME, Fábio M. Data: 02/02/2007.

O cortejo terrestre se transforma em um cortejo marítimo, quando os membros do cortejo são levados para um pequeno barco com todos os presentes e atabaques, para uma escuna onde os Ojé, os Alabés e a hierarquia feminina continuam cantando e dançando as músicas sagradas, mantendo o fluxo de axé sobre as águas. Começa então o cortejo marítimo com a praia cheia de gente; com diversos barcos, escunas e lanchas decorados e abarrotados de gente; navegando na Baía de Todos os Santos para o mesmo lugar onde todos os anos eles entregam os presentes dos Babás para Iemanjá, na esperança de que seus pedidos sejam atendidos. O cortejo se desterritorializa da terra, das ruas de Ponta de Areia, e se reterritorializa no mar (ver Figura 10). Torna o mar sagrado no instante em que flui sobre as ondas da Baía de Todos os Santos. O cortejo marítimo leva o tempo e espaço sagrado do terreiro para o espaço e tempo profano do dia a dia do mar. 
Fig. 10: Os membros da sociedade de culto a ancestralidade embarcam para levarem os presentes a Iemanjá.

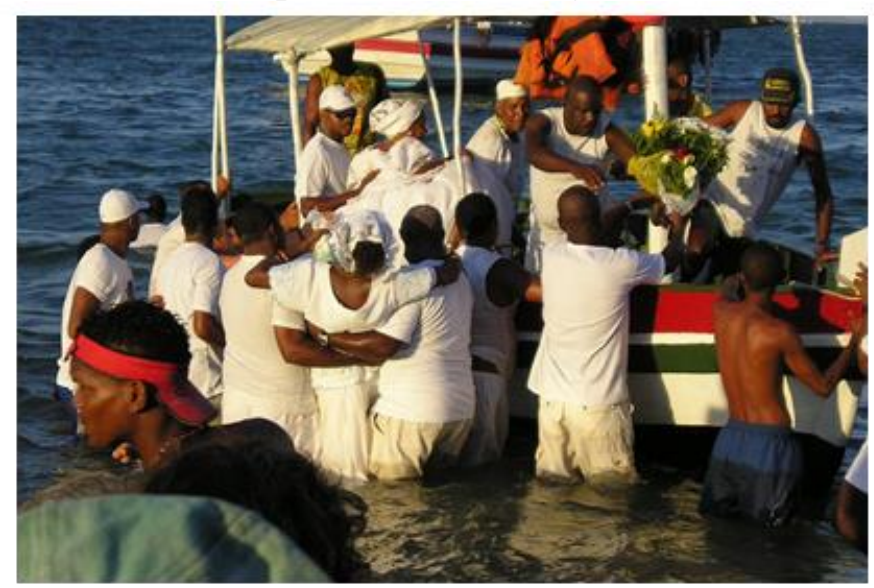

Fonte: VELAME, Fábio M. Data: 02/02/2007.

Quando o cortejo chega ao local tradicional das oferendas a Iemanjá, no instante da doação da vaza dos vasos com os presentes que levam os axés dos Babás e os pedidos e esperanças de seus filhos, se instala o Omo Ilê Agboulá. Ali, sobre o mar, está o terreiro, porque o terreiro também são os seus filhos no exato instante sagrado do ritual da oferenda a rainha do mar, Iemanjá. Esta corrente começou dentro do terreiro do Omo Ilê Agboulá, invadiu as ruas de Ponta de Areia e navegou sobre as vagas da Baía de Todos os Santos ao som dos atabaques e das cantigas sagradas da sociedade de culto aos Egum.

Enquanto no mar os filhos de Agboulá no terreiro sobre barcos entregam os presentes a Iemanjá, na praia de Ponta de Areia, inúmeras Erelu, as cantadoras de Egum, ficam na praia, juntas, à espera do regresso do cortejo para ter a certeza de que os presentes foram entregues conforme os preceitos, sem poder começar as atividades lúdicas. Só com o regresso do cortejo marítimo à praia estará terminado o ritual sagrado nos espaços profanos das ruas de Ponta de Areia. Tem início a festa profana graças ao bom andamento do ritual sagrado. Sob as bênçãos dos Babás, dá-se a festa profana que dura toda a noite até o raiar do dia nas barracas de praia e na praça do Povoado de Ponta de Areia, pois tudo ocorreu conforme as recomendações e solicitações dos Babás. O sagrado e profano no candomblé não são duas categorias opostas e dicotômicas, elas andam de mãos dadas, coexistem, se conectam e se alimentam mutuamente, acontecem de forma simultânea, um está presente na realização e acontecimento do outro. 
Todos esses espaços e lugares sagrados do culto aos Egum em Ponta de Areia oriundos de diversos processos de desterritorializações e reterritorializações do Omo Ilê Agboulá pela cidade em virtude das perseguições policiais nos anos de 1940 e da especulação imobiliária nos anos de 1960 a 1980 originou, nesse nomadismo forçado, permanências, reminiscências e vestígios de elementos e lugares sagrados do culto espalhados por toda a cidade, tais como: o lugar onde o terreiro foi fundado (que hoje se encontra a capela de Nossa Senhora das Candeias) que possui um forte simbolismo para os membros do culto; os assentos de divindades como Exu, Iroco (Gameleira Branca), Ogum (Cajazeira) que ainda são cultuados em datas específicas na proximidade da capela; uma fonte sagrada de Oxum que hoje está localizada em uma propriedade privada próximo ao Barro Vermelho; uma mata sagrada antiga no Barro Vermelho utilizada ainda hoje no cotidiano pelo Omo Ilê Agboulá e por vários outros terreiros de Egum de Ponta de Areia; o lugar no mar em frente a praia, onde ficam os Ojés pescadores, onde deve ser fincada todos os anos a bandeira que abre o ciclo da festa das águas; o assento de Exu Bará, o Exu individual de cada um, nas casas dos membros do culto. Todos esses lugares ainda são usados no cotidiano dos membros do culto aos Egum e se potencializam durante o ciclo das Festas das Águas (a Botada da Bandeira no dia 20/01, a Festa dos Presentes a Iemanjá no dia 02/02, e a Retirada da Bandeira no dia 20/02).

Os cortejos das festas das Águas do Culto aos Egum nascem dentro do terreiro e passam em seus trajetos simbólicos, por esses diversos lugares, realizando vários rituais e reverências. As festas e cortejos afro-brasileiros nos espaços públicos da cidade desvelam a rede de lugares sagrados, a rede de ancestralidade afro-brasileira que estrutura e organiza a cidade, permeia a vida urbana, e imprimi nela a resistência negra, a resistência e existência dos membros do culto aos Egum que ocorreu historicamente numa disputa e luta tenaz de sobrevivência na cidade brasileira racializada em três momentos: a perseguição policial e a criminalização dos anos 1920-1940; a especulação imobiliária e a expulsão branca dos anos de 1960-1980; e a intolerância religiosa dos cultos neopetencostais nos anos 2000.

Mas os Egum fazem-se presentes mesmo estando ausentes, são uma presença que se dá na ausência no cotidiano dos membros do culto aos Egum os acolhendo, orientando-os, conduzindo-os nas mazelas, desventuras e infortúnios da existência, lembrando-os de onde vieram, da mãe África, filhos da diáspora negra no mundo 
atlântico, filhos de Agboulá, herdeiros de Oyo, zeladores do segredo africano da vida e da morte, de trazer do Orum os seus ancestrais para que juntos possam resistir na forma de ser e estar no mundo africano e afro-brasileiro.

\section{REFERÊNCIAS BIBLIOGRÁFICAS}

BASTIDE, Roger. O Candomblé da Bahia. São Paulo: Ed. Schwarcz Ltda, 1980.

BRAGA, Julio. Ancestralidade Afro-Brasileira: $O$ culto de Babá Egum. Salvador: Ed. EDUFBA, 1995. . Ancestralité et vie quotidienne: le culte de babá egum à Ponta de Arei'. Strasbourg: Ed. Reproduction, Moderne, 1986.

. Ancestralidade afro-brasileira. Religião e Cidadania, Salvador, Ed. EGBA/UFBA, p.11-28, 1990.

. Ancestralidade em ponta de Areia; mulheres, crianças e o exercício da autoridade. Revista Bahia, Salvador, $n^{\circ} 14$, p. 29-34, set./nov. 1989.

Gente de Ponta de Areia: ancestralidade na dinâmica da vida social de uma comunidade afro-brasileira. Revista Gente, Salvador, FFCH/UFBA, nº1, p.19-37, 1984.

O dinheiro do chão e a hierarquia: aspectos da organização sócio-econômica do culto de babá egum. Revista Padê, Salvador, no 01, p.37-44, jul.1989.

O culto de egum em Ponta de Areia, Itaparica, In: REIS, João (org.), Escravidão \& invenção da liberdade; estudo sobre o negro no Brasil, São Paulo: Ed. Brasiliense, p.198-214, 1988.

CAETANO, Vilson; SOARES, Cecilia; VELAME, Fábio. Processo de Reconhecimento de Patrimônio Material e Imaterial Afro-Brasileiro do terreiro de culto aos Egum, Omo Ilê Aboulá. Salvador, 2006.

DELEUZE, G.; GUATTARI, F. Mil Platôs: Capitalismo e esquizofrenia, vol.4. São Paulo: Ed. 34, 1997.

Mil Platôs: Capitalismo e esquizofrenia, vol.5. São Paulo: Ed. 34, 1997.

ELIADE, Mircea. Imagens e símbolos: ensaios sobre o simbolismo mágico-religioso. São Paulo: Ed. Martins Fontes, 1991. 1992. O sagrado e o profano: a essência das religiões. São Paulo: Ed. Martins Fontes,

FILHO, Aulo B. Eguns, Os Espíritos Ancestrais - O Culto dos Eguns no Candomblé. Revista Planeta, São Paulo, nº 162, p.43-49, 1986.

FOUCAULT, Michel. Em Defesa da Sociedade. São Paulo: Ed. Martins Fontes, 2005. História da Loucura. São Paulo: Ed. Perspectiva, 2007. Microfísica do Poder. Rio de Janeiro: Ed. Graal, 1979. Nascimento da clínica. Rio de Janeiro: Ed. Forense Universitária, 2004. Os Anormais. São Paulo: Ed. Martins Fontes, 2002. O Poder Psiquiátrico. São Paulo: Ed. Martins Fontes, 2006. Vigiar e Punir. Rio de Janeiro: Ed. Vozes, 2007.

GEERTZ, Clifford. A Interpretação das Culturas. Rio de Janeiro: Ed. Zahar,1978. Vozes, 2004.

O saber local: novos ensaios em antropologia interpretativa. Rio de Janeiro: Ed. 
LIMA, Vivaldo da C. O Conceito de "nação" nos candomblés da Bahia. Afro-Àsia, Salvador: Centro de Estudos Afro-Orientais da UFBA, n.12, p.65-90, jun.1976.

LODY, Raul. Espaço Orixá e Sociedade, Arquitetura e Liturgia do Candomblé. Salvador: Ed. Ianamá, 1984.

MOURA, Carlos Eugênio Marcondes de (coord). Oloorisa: Escritos sobre religião dos orixás. São Paulo: Agora, 1981.

OLIVEIRA, Reinaldo José de. Resenha Segregação Urbana, Identidade e Saúde da População Negra: questões para a psicologia. Revista da Associação Brasileira de Pesquisadores/as Negros/as (ABPN), v. 10, n.24, p. 260-263, fev. 2018. ISSN 2177-2770. Disponível em: <https://abpnrevista.org.br/index.php/site/article/view/584>. Acesso em: 17 março, 2020.

SANTOS, Deoscoredes M.; SANTOS, Juana E. O Culto dos Ancestrais na Bahia: O Culto dos Eguns. In: MOURA, Carlos E. M. (org.), Oloorisa, escritos sobre a Religião dos Orixás. São Paulo: Ed. Agora, 1981.

SANTOS, Deoscoredes M. Festa de Mãe d'Água em Ponta de Areia, Itaparica. Revista Brasileira de Folclore, Rio de Janeiro, Ed. Campanha de Defesa do Folclore Brasileiro, vol.6, nº14, p.65-74, 1976.

SANTOS, Juana E. Os nagôs e a morte: pade, asese e o culto de egum na Bahia. Rio de Janeiro: Ed. Vozes,1998.

SECNEB, 1997. Ancestralidade Africana no Brasil: Os 80 anos de Mestre Didi. Salvador: Ed. . Egungum - Ancestralidade Africana no Brasil. Salvador: Ed. SECNEB, 1980.

SILVA, Merilene R. N. Negros na Rua. Rio de Janeiro: Ed. Martins Fontes, 1994.

SOUZA. Vilson C. Nagô: A nação de ancestrais intinerantes. Salvador: Ed. Fib, 2005.

VELAME, Fábio M. A Arquitetura do Terreiro de Candomblé de Culto aos Egum: O Omo Ilê Aboulá um Templo da Ancestralidade Afro-Brasileira. Salvador: Faculdade de Arquitetura da UFBA, 2007.

VELAME, Fabio M. O Lessayn: O Coração de um Terreiro de Egum. Revista Eletrônica da Palmares, v.06, p.01-15, 2006.

VELAME, Fabio M. Dos Orixás Invisíveis aos Orixás Visíveis: Um ensaio sobre a mercantilização dos deuses nagôs na Bahia. In: Simpósio Latino-Americano: Cidade e Cultura - Dimensões Contemporâneas, SIILLAC 2007, USP São Carlos. São Paulo, 2007.

VERGER, Pierre. Fluxo e Refluxo do Tráfico de Escravos entre o Golfo de Benin e a Baía de Todos os Santos dos Séc. XVIII a XIX. São Paulo: Ed. Corrupio, 1987.

Os Orixás. Salvador: Ed. Corrupio, 2002.

Recebido em: 22/09/2020

Aceito em: 30/10/2020 